\begin{tabular}{|c|c|c|}
\hline OSNED & $\begin{array}{c}\text { Osmanlı Medeniyeti Araştırmaları Dergisi } \\
\text { Journal of Ottoman Civilization Studies } \\
\text { Cilt 6, Sayı 10, Nisan } 2020 \text { \& Vol 6, No 10, April } 2020 \\
\text { @2019 Telif Hakkı OSMED’e aittir }\end{array}$ & 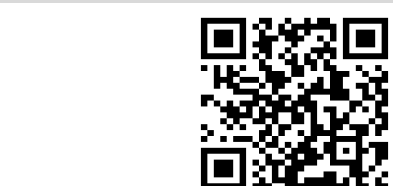 \\
\hline DOI: 10.21021/osmed.660603 & Makale Türü: Araştırma Makalesi & Article Types: Research Article \\
\hline Geliş Tarihi \& Received: 17.12.2019 & Kabul Tarihi \& Accepted: 10.03.2020 & OSMED, 2020, 6(10): $64-82$ \\
\hline
\end{tabular}

\title{
Kudüs'te Bir Tenkiziyye Medresesi: Osmanlı Tatbikinde Hayrî Bir Vakıf Eserin Akara Tebdîli Mümkün Müdür?*
}

\author{
Madrasa Tankiziyya in Jerusalem: Was it possible for a Charitable Waqf Property to be turned into \\ an Asset in Ottoman Practice?
}

\section{Şerife EROĞLU MEMIŞ**}

\section{$\ddot{O} \mathbf{z}$}

Çalışma, Şam Naibi Emîr Tenkiz tarafından Kudüs'te kurulan Tenkiziyye Medresesi ve vakfını vakfiyesi bağlamında inceleyerek, medresenin tarihi gelişimine ilişkin bir değerlendirme sunmayı amaçlamaktadır. Zira medrese binası 16. yüzyıldan itibaren Kudüs Kadısı tarafından kullanılmıştır. Öte yandan, her ne kadar medresenin ve vakfının kuruluşuna ilişkin bazı çalışmalar bulunsa da vakfın tarih içerisindeki serüvenini takip eden çalışmalara olan ihtiyaç devam etmektedir. Bu bağlamda çalışma üç bölümden oluşmaktadır. Birinci bölümde medreseyi vakfeden Emîr Tenkiz ve vakfettiği medrese tanıtılacaktır. İkinci olarak, medresenin yönetimi, görevli istihdamı, medreseye vakfedilen akarlar vakfiyesinde belirtildiği şekliyle incelenecektir. Vakfin tarihi gelişimine ilişkin Kudüs Şer'iye Sicillerinde, Osmanlı arşiv kayıtlarında ve diğer tarihi belgelerde yer alan vakıf kayıtlarına da başvurulacaktır. Üçüncü bölümde, medrese binasının Osmanlı Dönemindeki kullanım değişikliği, Osmanlı'da mevcut diğer uygulamalarla karşılaştırılarak, gerekçeleri ile değerlendirilmeye çalışılacaktır.

Anahtar Kelimeler: Kudüs, medrese, Tenkiziyye Medresesi, vakıf, Osmanlı Tarihi.

\begin{abstract}
This study aims to present an evaluation of the historical development of the Tankiziyya Madrasa and its waqf established by al-Amir Tankiz in Jerusalem in relation to its waqfiyya. Because the madrasa building had been used as shariah court by the kadi (judge) of Jerusalem from the 16th century. On the other hand, although a number of studies have explored the establishment of the madrasa and its waqfiyya, there is a continuing need for studies that follow the changing nature of this institution over time. In this context, the study consists of three parts. In the first part, the endower and the madrasa will be introduced. In the second part, the administration of the madrasa, the employement of the officials, the assets dedicated to the madrasa will be examined as situated in the waqfiyya. In the third part, changes in the functions of the madrasa in the Ottoman period will be discussed in relation to the other similar applications in the Ottoman State with its reasons.
\end{abstract}

Keywords: Jerusalem, madrasa, al-Madrasa al-Tankiziyya, waqf, Ottoman History.

\footnotetext{
* Bu makale, 20-22 Ekim 2017 tarihleri arasında Konya'da düzenlenen 1. Uluslararası Sosyal Bilimler ve Müslümanlar Kongresi'nde "Kudüs'te Bir Medrese Vakfı: Tenkiziyye Medresesi, Vakfiyesi ve Tarihsel Gelişimi" başlığı altında sunulan bildirinin yeniden gözden geçirilmiş ve genişletilmiş halidir.

** (Dr.) Vakıflar Genel Müdürlüğü, serife_eroglu@yahoo.com; ORCID: orcid.org/0000-0003-2880-8602
}

Kaynak Gösterme: Eroğlu Memiş, Ş. "Kudüs’te Bir Tenkiziyye Medresesi: Osmanlı Tatbikinde Hayrî Bir Vakıf Eserin Akara Tebdîli Mümkün Müdür? ". Osmanlı Medeniyeti Araştırmaları Dergisi, 6 (2020): 64 - 82. 


\section{Giriş}

Yüzyıllar boyunca İslam toplumlarında ve devletlerinde önde gelen kurumlar arasında yer alan vakıflar sayesinde Kudüs'te de pek çok hayrî, sosyal, beledî, dinî ve eğitim hizmetleri yerine getirilmiştir. ${ }^{1}$ Mescid-i Aksâ ya da Harem-i Şerîf olarak da adlandırılan alan kuruluşuyla birlikte Kudüs şehir merkezine hâkim olmuş ve İslâm devletlerinin de sembolik merkezi haline gelmiştir. Harem-i Şerîf, zaman içerisinde, şehir merkezini kuşatan ve idari sistem ve kentsel hizmetler örgütlenmesinin bir parçası olan geniş bir vakıf $a \breve{g}_{l}^{2}$ nın da merkezini oluşturmuştur. Eyyûbî, Memluklü ve Osmanlı dönemlerinde gerek Harem-i Şerîf içerisinde gerekse etrafinda yer alan vakıf emlakı gerek maddi gerek manevi anlamda çok büyük öneme sahip olmuştur. ${ }^{3}$

Vakıf, esasında, bir mülkün belirli bir hayır işine ebedi olarak tahsis edilmesi anlamına gelmektedir. Vâkıf (vakfın kurucusu), mülkiyet haklarından feragat edip, vakfın hayır amacını ve artık "Allah'ın mülkü" olan vakıf mülkünün işletilmesiyle ilgili kuralları vakfiyesinde belirlemekte idi. Vakıf mülkü bir piyasa metaı olmaktan tamamen çıkıyor; satış, hibe veya rehin ne şekilde olursa olsun temlikine kesinlikle yasak geliyordu. ${ }^{4}$ Söz konusu mülkler genellikle, kendileri de vakıf statüsünde olan "hayrât"ların istifadesi için kurulmakta idi. Vakıflar, gelir ve kâr sağlayan mülkler olabileceği gibi bu gelirleri kullanarak dinî veya sosyal hizmet sunan birimler de olabiliyordu. Mesela, tarım arazileri vakfa dönüştürülmüş ve gelirleri belirli bir cami, medrese, mektep ve müştemilatlarının inşası ve bakımına tahsis edilmiş olabiliyordu. ${ }^{5}$

Osmanlılar Kudüs'ü topraklarına kattıklarında, şehirde 50'den fazla medrese, düzinelerce âlim ve bu medreselere devam eden yüzlerce öğrenci bulunmakta idi. ${ }^{6} \mathrm{Bu}$ medreselerin tamamı vakıftı, yani medreselerin yönetimi ve devamlılığı vakıflar aracılığı ile sağlanmakta idi. Vâkıf, kurduğu müessesenin nasıl işletileceğini, vakfının şartları arasında belirtir ve bu şartlar kimse tarafından değiştirilemezdi. Bu müesseselerin personel tayin hakkı da tamamıla vakıf kurucusuna ait olup, vâkıflar müderrisleri ve medresenin diğer elemanlarını ya doğrudan kendileri tayin etmekte veya vakfiyelerine bu konuyla ilgili şartlar koymakta idiler. ${ }^{7}$ Bu bağlamda, vakfiyeler geniş bir yelpazede vakıflarla ilgili önemli ve detaylı bilgiler içeren, vakıf sisteminin, aynı zamanda da bireysel vakıfların en temel arşiv kaynaklarından birisidir. Vakıfların kuruluşlarının hukuki belgeleri olan vakfiyeler, onaylanmaları ile vakfa hukuki statüsünü kazandırırdı. ${ }^{8}$ Ancak vakıfların zaman içerisindeki değişimini takip edebilmek adına diğer

1 Örn. bkz. Mucireddîn el-Hanbelî el-'Uleymî, el-Ünsü'l-Celîl bi-Târîhi'l-Kudsi ve'l-Halîl, C. II. (Amman, 1973); 'Arif el-'Arif, elMufassal fî Târîhi'l-Kuds, (Kudüs, 1961); Kamil Cemil el-Aselî, "Kudüs," Diyanet Vakfı İslam Ansiklopedisi, C.26 (2002), 334-338; Abdüllatif Tibawi, The Islamic Pious Foundations in Jerusalem, (London, 1978); Mehmet Tütüncü, Turkish Jerusalem (15161917). Ottoman Inscriptions From Jerusalem and Other Palestinian Cities, (Netherlands: SOTA, 2006).

2 Kudüs vakıfları üzerine yapılan çalışmada "vakıf ağı" kavramı Ömer Lütfi Barkan tarafından "hayrât siteleri" ve Bahaeddin Yediyıldız tarafından "vakıf hayrât sistemi" kavramlarına alternatif bir kavram olarak sunulmuştur. Detaylı bir inceleme için bkz. Şerîfe Eroğlu Memiş, "Osmanlı Taşra Toplumu ve Vakıf Kurumu: Kudüs, 1703-1831” (doktora tezi, Hacettepe Üniversitesi, 2016), 58-151.

3 'Arif el-'Arif, Tarîh-i Kubbetü's-Sahratullahü'l-Müşerrefe ve'l-Mescidü'l-Aksâ ve limahhatu 'an Târîhi'l-Kuds, (Kudüs: Mektebetü'I-Endülüs, 1947); Michele Bernardini, "Popular and symbolic iconographies related to Haram al-Sharif during the Ottoman period," in Ottoman Jerusalem, the living city: 1517-1917, S. Auld and R. Hillenbrand (ed.), (London: Altajir World of Islam Trust, Jerusalem 2000), 95-103.

${ }^{4}$ Ömer Hilmi Efendi, ithaf-ül-ahlâf fí ahkâm-il-evkaf, VGM Yay., (Ankara, 1977), 47.

5 Ömer Hilmi Efendi, ithaf-ül-ahlâf, 52-53.

${ }^{6}$ Kudüs'te ilmi hayat ve medreselere ilişkin detaylı bilgi için bkz. S. D. Goitein and Oleg Grabar, "al-Kuds", Encyclopedia of Islam, Second Edition, Vol. V. (Leiden: E.J. Brill, 1978), 322-344.

${ }^{7}$ Bahaeddin Yediyıldız, "Vakıf Müessesesinin XVIII. Asırda Kültür Üzerindeki Etkileri," Türkiye'nin Sosyal ve Ekonomik Tarihi, yay. O. Okyar, H. İnalcık, (Ankara, 1980), 157-159.

8 Vakfiye tanımlamaları için bkz. Bahaeddin Yediyıldız, "Vakıf", Islam Ansiklopedisi, C. XIII, (İstanbul: MEB Yay., 1986), 153; W. Heffening, "Waqf", Encyclopedia of Islam, Second Edition, (Leiden: E. J. Brill, 1934), 1096- 1103; Amy Singer, Osmanlı'da 
bazı defter ve kayıtlara ihtiyaç vardır. Örneğin, vakıfların günlük hayatta fiili işleyişiyle ilgili bilgiler sunan Kudüs şer'iye sicilleri; vakfın yıllık gelir-giderlerinin tutulduğu muhasebe kayıtları; mahallinden İstanbul'a gönderilen şikâyetler üzerine kaleme alınan hükümleri ihtiva eden ahkâm ve şikâyet defterleri bu kaynaklardan önemli bazılarıdır. ${ }^{9}$

Çalışma konusunu da teşkil eden Tenkiziyye Medresesi binası 16. yüzyıldan itibaren Kudüs Kadısı tarafından davalara bakılan bir mekân olmuş, sonrasında ise Şer'î Mahkeme olarak kullanılmıştır. Hayrî bir amaçla vakfedilen ve yüzyıllar boyunca bu fonksiyonunu yerine getiren hayrî bir yapının, Osmanlı Dönemi'nde akara tebdîl edilmesinin mümkün olup olmayacağı sorusu da mevcut çalışmada odaklanılacak temel bir sorun olarak karşımıza çıkmaktadır. Öte yandan, her ne kadar medresenin ve vakfının kuruluşuna ve örneğin Memlükler Dönemi'nde işleyişine ilişkin bazı çalışmalar bulunsa da vakfın zamanla ne gibi yapısal ve fonksiyonel değişimlere uğradığını takip eden çalışmalara olan ihtiyaç devam etmektedir. ${ }^{10}$ Bu bağlamda mevcut literatüre katkıda bulunmayı amaçlayan çalışma üç bölümden oluşmaktadır. Birinci bölümde, medreseyi vakfeden kişi olan Emîr Tenkiz ve vakfettiği medrese tanıtılacaktır. İkinci olarak, Vakıflar Genel Müdürlüğü Arşivi’nde istinsâh nüshası bulunan medresenin vakfiyesi başta vakıf akar ve hayrâtları, vakfın yönetimi ve görevli istihdamı olmak üzere vakfiye yedi alt başlık altında incelenecektir. Vakfın tarihsel gelişimine ilişkin bir değerlendirme sunmayı amaçlayan çalışmanın üçüncü bölümde ise, yapının Osmanlı Dönemi'ndeki kullanım değişikliği, Osmanlı'da mevcut diğer uygulamalarla karşılaştırılarak, gerekçeleri ile açıklanmaya çalışılacaktır. Hayrî amaçla kurulan bir vakıf eserin akara tebdîlinin mümkün olup olamayacağı meselesi İslam fikhı açısından incelenecektir.

\section{1. Şam Nâibi Emîr Tenkiz ve Tenkiziyye Medresesi}

Emîr Seyfeddin Ebi Said Tenkiz, Memlukler Dönemi'nde 712-740 y1lları arasında Suriye valiliği yapmış ve bu vazifesi sırasında Kudüs'ü defalarca ziyaret etmiştir. Kudüs'e tarihinde en çok eser bırakan kişilerden biri olan Emîr Tenkiz, Sultan Nâsır el-Muhammed adına Kudüs'te büyük ticari bir yapı olan Sûk el-Kattanîn (Pamukçular Çarşısı) inşa etmiştir. Harem'in batı duvarının ortasında, Harem ile Tarîk el-Vâd arasında uzanan bu çarşı, Harem-i Şerîf'e Sultan Melik el-Nâsır Muhammed tarafından yeniden inşa edilen Bâb el-Kattanîn adlı kapı ile açılıyordu. ${ }^{11}$ Burgoyne, bu kapının daha eski bir kapının yapısı üzerine ve Sûk el-Kattanîn'in de bu bölgedeki bir haçlı çarşısının temelleri üzerine inşa edildiğini kaydetmiştir. Bu çarşının doğudan batıya uzunluğu 95m'dir. ${ }^{12}$

Gül'de aktarıldığg şekliyle, El-Umarî “Tenkiz, Kudüs'te ribât inşa etti ve çarşıya ve Harem'e Mescidü'l-Aksa kapısı üzerinden su getirdi ve onda iki hamam ve Kayseriyye inşa etti" diyerek çarşının yanında Kayseriyye'den ayrıca bahsetmektedir. ${ }^{13}$ Burada Kayseriyye çarşı içerisinde bir Han olmalıdır.

Hayırseverlik- Kudüs 'te Bir Haseki Sultan Imareti, çev. Dilek Şendil, (İstanbul, 2004), 124; Fuad Köprülü "Vakıf Müessesesi ve Vakıf Vesikalarının Tarihi Ehemmiyeti", Vakıflar Dergisi, S. 1, (Ankara, 1938), 1-6.

${ }^{9}$ Kaynaklara ilişkin detaylı bir inceleme için bkz. Kayhan Orbay, "Vakıfların Bazı Arşiv Kaynakları (Vakfiyeler, Şeriyye Sicilleri, Mühimmeler, Tahrir Defterleri ve Vakıf Muhasebe Defterleri)", Vakıflar Dergisi, 39 (2005), 27-41.

10 Tenkiziyye Medresesi'nin kuruluşu ve vakfiyesini inceleyen çalışmalar için bkz. Michael H. Burgoyne, Mamluk Jerusalem: An Architectural Study, (London: Published on behalf of the British School of Archaeology in Jerusalem by the World of Islam Festival Trust, 1986), 70, 198; Abdulcelil Hasan Abdulmehdî, el-Medâris fî Beyti'l-Makdîs fi'l-Asreyni'l-Eyyûbî ve'l-Memlûkî', (Amman: Mektebetü'l-Aksâ, 2009), 187-193. Abdulmehdi çalışmasında, Tenkiziyye (Seyfiyye) Dârü'l-Hadîs'inin ise Emîr Seyfeddin Tenkiz bin Abdullah en-Nâsıra tarafından 729 yılında Tenkiziyye Medresesi'nden ayrı bir bina olarak inşa edildiğini kaydeder. Shawkat Ramadan Hijjih and Othman Ismael el-Tel, "el-Medrese el-Tenkiziyye fî el-Kuds: nemûzecen li-idâreti'lmedâris ve evkâfihâ fî el-'asr el-Memlûkî”, Ankara Üniversitesi llahiyat Fakültesi Dergisi 56:1 (2015), 77-106.

11 Burgoyne, Mamluk Jerusalem, 277.

12 Burgoyne, Mamluk Jerusalem, 273-279.

13 Muammer Gül, 11-13 yüzyıllarda Kudüs, Fırat Üniversitesi Sosyal Bilimler Enstitüsü, (Elazığ, 1997), 75. 
Zira bu çarşıdaki mevcut kitabelerde Tenkiz'in inşa ettiği bu yapının içerisinde bir çarşı (sûk), bir han ve iki hamamdan bahsedilir. ${ }^{14}$ Gül'de yer aldığg şekliyle kitâbeler şöyledir:

“... (sağ kapıda) “Bu mübarek kapı bizim Efendimiz Sultan'ın günlerinde yapıldı. Sultan, yardım eden, zeki, Kutsal savaşın kavgacısı, imanın müdafaacısı, sinırların koruyucusu, muzaffer İslâm'ın ve Müslümanların sultanı, inançsız ve putpererestlerin öldürücüsü. Dünyada adaleti yeniden kuran, ezilmişleri ezenlerden koruyan, Müslüman toplumların yardımcısı Nâsır ed-Dünya ve'd-Dîn Sultanoğlu Muhammed." (sol kapıda) El-Mansur Seyfü'd-Dünya ve'd-Dîn Kalavun es-Salihi. Allah onun zaferlerini artırsin ve güçlendirsin idaresini ebedileştirsin. Allah onun askerlerine ve bekçilerine yardım etsin, bayrağını yüceltsin, her iki cihanda saadet versin, Kudüs-I Şerîf'in yüce Haram'ı için, en yüce emredici Tenkiz en-Nâsır (asil Suriye (Şam) memleketlerinin koruyucusu, Allah yardımcılarına gü̧̧ versin. 736 (1336) senesinin şu aylarında..."

Sûk al-Kattanîn Caddesi üzerinde bulunan bu iki hamamdan biri Hamam el-Şifa olub çarşının doğu ucunda, diğeri ise Hamam el- 'Ayn olup çarşının batı bölgesinde bulunmaktadır. Her ikisinin de kitâbesi yoktur. ${ }^{15}$ Hamam el-'Ayn, Bahar Hamamı olarak da bilinmekte, yapıldığı dönemde Yeni Hamam veya kurucusunun adı olan Tenkiz Hamamı olarak adlandırılmakta idi. Hamam el-Şifa (Şifa Hamamı) ise Aşure Hamamı olarak da adlandırılmakta idi. İnanışa göre Zemzem sularının taşarak, Muharrem ayının 10. Günü Şifa Hamamı'nın sularına karışması nedeniyle bu isim verilmiştir. Böylece, suyunun şifalı olması nedeniyle cilt hastalıklarına iyi geldiğine inanılmıştır. ${ }^{16}$

Harem-i Şerîf'i çepeçevre saran ve kentin görsel arşivinin bir parçası olan Şam Nâibi Emîr Tenkiz en-Nâsırî'nin 729/1329'da yaptırdığg Tenkiziyye Medresesi ile Sûkü'l-Kattanîn bu yapılardan en görkemlileri arasında zikredilmiştir. ${ }^{17}$ Silsile Kapısına bitişik inşa edilmiş olan ve gelirlerinin medreseye vakfedildiği bir vakfı da olan Tenkiziyye Medresesi'nin Aksa avlusu ve Silsile Kapısı içinden olmak üzere iki ayrı girişi vardır. Ancak anıtsal ana girişi Silsile Kapısının içerisindendir. ${ }^{18}$

Memluk mimari tarzında yapılan Tenkiziyye Medresesi iki katlıdır. Birinci katta, medrese, dârü'lhadis, mescid ve mektebe (kütüphane), fakihlerin, öğrencilerin ve diğer görevlilerin ikameti için odalar bulunmakta idi. Alt katındaki odalarda Hanefi fikhı âlimleri ikamet etmiş ve ders vermiştir. Medresenin ikinci katında ise Sufi hangâh, sufiler için mescid ve bu yapının üst katındaki 11 odasında sufiler ikâmet etmiştir. Medresenin toplamda 22 hücresi vard. ${ }^{19}$

Tenkiziyye Medresesi, Memlükler Döneminde kadı ve nâibler için bir ilim merkezi haline gelmiştir. Kudüs'e uğrayan protokol misafirlerinin de zaman zaman Tenkiziyye'de ağırlandığı bilinmektedir. Memluklülerin ilk Çerkez hükümdarı Berkuk'un oğlu Sultan Farac Kudüs'ü ziyaretinde bu medresede ağırlanmıştır. Osmanlı Dönemi’nde şer‘î mahkeme olan medrese, İngiliz yönetiminin ilk yıllarına kadar bu şekilde kullanılmaya devam etmiştir.

\footnotetext{
14 Kitabelerin Arapça ve İngilizce tercümeleri için bkz. Oleg Grabar, "A New Inscription from the Haram al-Sharif in Jerusalem", Jerusalem, Vol. IV, Constructing the Study of Islamic Art, (Hampshire: Ashgate Publishing Limited, 2005), 47-58. Türkçe tercümeleri Muammer Gül'ün yayınlanmamış doktora çalışmasında yer almıştır.

15 Burgoyne, Mamluk Jerusalem, 76.

16 Taufik Canaan, "Water and 'The Water of Life' in Palestinian Supersitition", Journal of the Palestine Oriental Society 9: 57 (1929), 66.

17 Baha Tanman ve A. Vefa Çobanoğlu, "Osmanlı Döneminde Kudüs: Kent Dokusu, Mimarlık ve Çini Sanatına Iliş̧kin Bir Araştırmanın Illk Sonuçları”, Ortadoğu'da Osmanlı Dönemi Kültür Izleri Uluslararası Bilgi Şöleni Bildirileri (25-27 Ekim 2000, Hatay), (Ankara: Atatürk Kültür Merkezi Başkanlığı Yay., 2001), 519-528; Cengiz Tomar, "Kudüs” (Memlükler Dönemi), Diyanet islam Ansiklopedisi, C. 26, (İstanbul, 2002), 334; Johns Pedersen, "Mescit”, Islam Ansiklopedisi, C. VIII, (İstanbul: Milli Eğitim Bakanlığı Yay., 1993), 54.

18 el-Hanbelî, el-Ünsü'l-Celîl, 35; David S. Powers, "Revenues of Public Waqfs in Sixteenth Century Jereusalem", Archivum Ottomanicum, Vol. 9, (Germany: Wiesbaden,1984), 169.

19 VGMA, 601-1: 55/63.
} 


\section{Tenkiziyye Medresesi Vakfiyesi}

El-Hanbelî Tenkiziyye (Dengiziyye) Medresesi'nin vakıf olarak Şam Nâibi Emîr Tenkiz el-Nasîrî tarafindan H. 729/ M. 1329 tarihinde kurulduğunu kaydeder. ${ }^{20} 522$ numaralı Evkaf Tahrir Defteri'nde vakfiyesinin bir kopyasının H. 730/ M. 1330 yılında yazıldığı belirtilirken, Powers da, medresenin kapısında bulunan kitâbede vakfiye tarihinin H. 729/ M. 1328 olduğunu belirtir. ${ }^{21}$ Vakıflar Genel Müdürlüğü Arşivi (VGMA)'da kayıtlı istinsâh nüshası da H. 730/ M. 1330 tarihlidir. $^{22}$

Bir vakfiyenin hukuken geçerli olabilmesinin en önemli koşulu sicile kaydedilmiş olması idi. Hanefi hukukçuları sicile kaydedilmedikçe vakfiyenin yalnız başına hüccet (delil) olma özelliği taşımayacağı ve vakfin hükmî şahsiyet kazanamayacağı görüşündedirler. ${ }^{23}$ Ancak vakfiyelerde çoğu zaman vakfiyenin tanzim edildiği yani yazıldığı tarihlerden ayrı olarak, tescil edildiği yani istinsâh kopyasının kaydedildiği tarihler de yazılmıştır. Çoğu durumda vakfiyenin başına not edilen bu kayıt, bazı vakfiyelerde sonda yer almıştır. Vakfiye metinleri başlamadan önce vakfiyelerin hangi süreçler sonucunda ve ne gerekçe ile kaydedildikleri yazılmıştır. Bazı vakfiyeler ilgili Kadılıkça çok önceden tanzim edilmesine rağmen, tescil edildikleri tarihler de bazı vakfiyelerin başında ve bazı vakfiyelerin de sonunda ayrica not edilmiştir.

Medreseye ait VGMA'da istinsâh nüshası kayıtlı vakfiyenin giriş sayfasında;

“İ̧̧bu vakfiyye Şûrâ-yı Evkâfin 21 Temmuz 331 tarihli karârına müsteniden 3 Rebi 'u'l-evvel 334 tarihinde sudûr iden irâde-i 'âliyye mucibince kaydolundu.

Kayd bi-zini'l-mevle'l- 'âlim el- 'âmil el-müdekkîk el-kâmil Seyyid Kuzâtü'l-İslâm senedü'l-mevâli'l'zzâm Hasenetü'l-leyâli ve'l-eyyâm Abdülhalim Mustafa -dâme uluvvihî- fi evâil-i şehr-i Cemâziye'l"ûlâ 1020."24

notu düşülmek suretiyle vakfiyenin evâil-i Cemaziyelevvel 1020/ Haziran-Temmuz 1611 tarihinde Kadı Abdülhalim Mustafa tarafından onaylanarak tanzim edildiği, vakıf hükmi şahsiyeti kazanan vakfiyenin 3 Rebiulevvel 1334/ 09 Ocak 1916 tarihinde tescil edildiği kayıtlıdır.

Vakfiyeler metinleri bakımından incelendiğinde kesin başlıklarla ayrılmasa da belirli bir düzene göre kaleme alınmışlardır. Örneğin, Yediyıldız tarafından vakfiyelerin içeriğine yönelik yapılan tasnife göre ideal bir vakfiye başlıca yedi bölümden oluşur. ${ }^{25} \mathrm{Bu}$ bölümler ise: Kadı onayı, dua, vâkıf, akar ve hayrât1, gelir kaynakları, hayır hizmetleri ve personel, hakimin görüşü ve dua-beddua şeklinde sıralanmıştır. ${ }^{26}$ Akar ve hayrâtı az olan veya nukud vakıfları gibi küçük vakıflara ait vakfiye veya zeyl vakfiyelerde bu yedi bölümün tümünü bir arada görmek olanaksızdır.

Çalışmanın bu kısmında bahse konu vakfiye de bu başlıklar altında incelenecektir.

Kadı Onayı: Vakfiyenin bu ilk bölümünde kurulan vakfın kurulduğu şehir ve şehrin elkâbı/lakabları (Medîne-i Sarây Bosna, Halebü'ş-Şehbâ, Âsitâne-i 'Âliyye, Medîne-i İzmir humiyyet ani'l-âfât ve'dtedmîr) ile vakfiyenin vâkıfın statüsüne göre kaç kadı (kadı-asker, nâib, hâkim) tarafından onaylandığı, bazen padişah tuğraları veya mühürler de yer aldığı görülür.

20 el-Hanbelî, el-Ünsü'l-Celîl, 35.

21 Powers, "Revenues of Public", 169.

22 VGMA, 601-1: 55/63.

${ }^{23}$ Ali H. Berki, Vakfa Dair Yazılan Eserler ile Vakfiye ve Benzeri Vesikalarda Geçen Istılah ve Tabirler, (Ankara: VGM Yay., 1966).

24 VGMA, 608-1: 55/63.

${ }^{25}$ Bahaeddin Yediyıldız, XVIII. Yüzyılda Türkiye'de Vakıf Müessesesi, Bir Sosyal Tarih incelemesi, (Ankara: TTK, 2003), 4-5.

${ }^{26}$ Yediyıldız, XVIII. Yüzyılda, 4-5. 
VGMA'da kayıtlı Tenkiziyye Medresesi'ne ait vakfiyenin Kadı Abdülhalim Mustafa tarafından Evâil-i Cemaziyelevvel 1020/ Temmuz 1611 tarihinde tanzim edildiği kayıtlıdır. Ancak vakfın kuruluş tarihinin 730/1330 olduğu dikkate alındığında bu tanzimin ikinci bir tanzim olduğu ve sicillere kaydedilği anlaşılmaktadır. ${ }^{27}$

Duâ: Vakfiyeler genellikle besmele ile başlar. Allah'a hamd ve Hazret-i Peygambere salât u selâm getirildikten sonra, vâkıfın hangi gerekçelerle vakfını kurduğu çeşitli ayet ve hadislere referansla izah edilir. Bu bölüm bazen bir paragraf, bir sayfa ya da birkaç sayfa devam edebilir.

Tenkiziyye Medresesi'ne ait vakfiyede de Allah'a hamd ve Hazret-i Peygambere salât u selâm getirildikten sonra, vakfın kuruluş gayesi Allah'a en güzel bir şekilde karz-ı hasende bulunarak, felah ve kurtuluşa erişmenin vesilesinin sadaka vermek olduğu dile getirilmiştir. Vakfetmek sureti ile yapılan sadakaların Allah katında çok değerli ve mertebesinin yüksek olduğu, çünkü bunların sadaka-i câriye (hayrı, sevabı daim olan sadaka) olduğu vurgulanmıştır. Bahse konu vakfiye ile vakfettiği sadakalarla vâkıfın Allah'a yaklaşmayı, O’nun rahmet ve fazlını kazanmayı mübâderet ettiği bildirilmiştir.

Vâkıf (Kurucu): Bu bölümde vakıf kurucusu olarak vâkıf tanıtılır. Erkek veya kadın, kimin oğlu veya kızı, unvanı, vakıf kurduğu sırada hangi unvanı taşıdığ veya önceki unvanın ne olduğu anlatılır. Aynı zamanda gerek soy bağı gerekse toplumsal statüsü de göz önüne alınarak vâkıfın çeşitli sıfatlarla övüldüğü, tarihi ve dini bakımdan önemli kişilerle kıyaslandığı görülür. Özellikle padişah ve hanım sultan vakfiyelerinde bu oldukça edebi bir dille anlatılır.

İncelenen vakfiyede de vâkıf; "İslâmın rüknü, en 'âmın zuhrü, ümerânın meliki, fukaranın sı̆̆ııă̆ı" ve vakfiyede yazılı birçok evsaf ve medâyihle tavsif edilmiş olan Şam Nâibi Nâsıralı Ebu Said Tenkiz bin Abdullah olarak kaydedilmiştir.

Akarlar ve hayrât: Bir vakfın kurulmasında en önemli unsur, vakfi oluşturan maddi alt yapı, yani vakfa gelir getirecek ve sonsuza dek vakfı ayakta tutacak malî kaynaklar yani akarlardır. Medreseye ilişkin vakfiyede vâkıfın 'Ayn-ı Kîna ismiyle bilinen köyün sınırlarını tanımlayarak, tanımladığı bu sınırları içerisinde bulunan bütün çiftlik, mezra'a, yazlık, kışlık alanlar, harman yerleri, değirmenler, zeytin ve portakal ağaçları ve türlü çeşit üzüm çubukları, bağ, bostan ve bahçeleri, meyveli meyvesiz bütün ağaçları, çiftçilerin oturmaları için mekânları, pınarların tamamını vakfettiği kaydedilmiştir. ${ }^{28}$

Vâkıf vakfettiği vakıf hayrât eserlerinin tamir ve bakımı, görevli ücretleri ve diğer masrafları için vakfiyesinde sınırları belirlenmiş 'Ayn-1 Kînâ olarak bilinen çiftlik ve mezra'aların tamamını

\footnotetext{
27 Başka bir örnekte Harem-i Şerîf'in batı köşesinde kalan ve Meğâribe mahallesi olarak bilinen alanın Selahaddin Eyyubî'nin oğlu Melik Efdal tarafından erkek ve kadın Mağriblilere vakfedildiği kayıtlıdır. Vakfiye, Melik Efdal sonrasında 666/1267 yılında -ki bu da Memlûk döneminin başlamasından sonraya tekabül etmektedir- tanzim edilmiştir. İkinci tanzim ise Osmanlıların bölgeye hâkim olduğu bir döneme denk gelen 1004/1595 yılında gerçekleşmiştir. Bkz. Tibawi, The Islamic Pious Foundations, 14.

28 "Kudüs-i Şerîf tevâbi'inden 'Ayn-ı Kîna nâmile ma'rûf çiftliğin ve mezra'alarının tamamı, bu çiftlik ve mezra'aları muattal ve ma'mul ve yumuşak ve sert ve uzak ve yakın ve yazlık ve kışlık yerleri ve putluğu ve harman yerlerini ve kış mevsiminin suları ile dönen değirmenleri ve zeytin ve turunç ağaçlarını ve dürlü üzüm çubuklarını ve bostan ve bağ ve bahçeleri ve incer ve harrup ve sâire ağaçlarını ve çiftçilerinin süknâsına mahsus dimneleri ve müte'addid pınarları müştemil olup kıblesi Nobyal karyesi arazısı ile ve tamamı Gönya karyesi arazisi ile şarkı Ramullah karyesi arazisi ile ve tamamı kedna karyesi arazisi ile şimali deyri beni Şaban karyesi arazisi ile ve tamamı Re's karyesi arazisi ile garbi Recaiye karyesi arazisi ile ve tamamı deyri yezi' karyesi arazisi ile mahduddur. Vâkıf; zikrolunan mevkûfatı; mezkûr ve gayr-i mezkûr ve mevsûf ve gayr-i mevsûf bilcümle hudûd ve hukuk ve tarâfik ve merâfikı ve aşağı ve yukarı mahalleri ve binaları, taşları ve mermerleri ve döşemeleri ve keresteleri ve demîrleri ve kapuları ve bilcümle aletleri ve kendisine mahsûs su yolları ve dahil ve hariç ve kendisiyle ma'rûf ve kendisine mensup bilcümle hakları ile birlikte vakfetti." VGMA, 601-1: 55/63.
} 
vakfetmiştir. Yukarıda bahsedilen iki de hamamı da vakfa gelir sağladığı için vakfın akarları arasında zikretmelidir.

$\mathrm{Bu}$ bölümde genellikle vâkıfın, vakfına gelir getirecek mal, mülk, para veya menkul niteliğindeki varlıkları, sermayenin işletimi ile ilgili şartları belirtilir. ${ }^{29}$ Medresenin vakfiyesinde vâkıf vakfın akarlarının işletilmesi ile elde edilecek gelirlerin ise vakfedilen çiftliğin ihtiyaçlarının karşılanmasına sarf edilmesini şart kılmıştır. Akarların işletilmesinin mümkün olmadığı durumlarda ise tamamının ya da bir kısmının kiraya verilmesini ve bu sürenin de iki yılı geçmemesi talep edilmiştir. Vakfiyede belirtilen iki hamamın ise bir yıldan fazla kiraya verilmemesini şart kılmıştır.

Yine bu bölümde vâkıfın yaptırdığı hayrât eserlerin adları (câmi '/ma 'bed-i münîf/kervansaray/ hânı kârbâna, tekye/tekke/tevhîd-hâne, dârü'l-kurrâ/kurrâ-hâne, darü'ş-şifâ/müsteşfâ/ hasta-hâne, kütüphâne/kitaphâne) çeşitli sıfatlarla betimlenmekte, nitelikleri, malzemeleri, yaptırma gerekçeleri detaylı bir şekilde anlatılmaktadır.

Tenkiziyye Medresesi vakfiyesinde ise vakfa ait beş hayrât eseri detaylı bir şekilde sınırları ve özellikleri ile tanımlanmıştır. Bunlardan ilki, Kudüs-i Şerîf'de Harem-i Şerîf civarında Bâb-1 Silsilede inşa ettiği müberek medresenin tamamıdır. Bu medrese fevkanî (üstte) ve tahtanî (altta) yirmi iki odadan oluşmakta ve fıkıh çalışmaları için (Hanefî fıkhı) 15 fakihe hizmet vermekte idi. Medrese içerisinde bir de cami binası bulunmaktayd1. Caminin bir mihrabı olmakla birlikte minber ve minaresi bulunmamaktaydı. Buradan hareketle $e l-A k s \hat{a}$ ve $e s-S a h r a ̂$ camilerinin yakın olmasından dolayı burada Cuma namazı kılınmadığı anlamını çıkarabiliriz. İkincisi, vâkıfın Harem-i Şerîf dâhilinde inşa etmiş olduğu mescid binasıdır. Bu mescide kuzey tarafından bitişik olan binaların tamamı ile mescidin bir takım müştemilatı ve sınai ve mimarî birçok mahasin de vakfedilmiştir. Üçüncüsü, söz konusu medresenin yakınında bulunan ve 12 daimî mukîm fakir kadın ile 10 misafir kadın taifesinin oturmaları için tahsis edilmiş ribâtın tamamıdır. Dördüncüsü, Kudüs’te değirmenler deresi olarak bilinen yerdeki iki hamamdır. Beşinci olarak da bu hamamlar yakınında vâkıfın inşa ettiği yedi gözü bulunan abdesthanenin tamamı vakfedilmiştir.

Vakfın sürekliliğinin sağlanmasında temel unsur olan akar ve hayrâtların ayakta kalması için vakfın gelirinden öncelikle bu yapıların tâ'mir ve termîmine ilişkin şartlar vakfiyenin bu dördüncü bölümünde zikredilir. Emîr Tenkiz vakfiyesinde mütevellinin vakfın kira ve mahsullerini öncelikle vakıf mevkûfatının tamiratına ve ihtiyaç duyan binaların yenilenmesi ve ıslahına sarf edilmesini şart kılmıştır. Önceliği vakıf mülklerin tâ‘mir ve termîmine vermiştir.

Vakıf Görevlileri ve Hayır Hizmetleri: Osmanlı vakıflarında çalışanlar temel olarak mütevelli (yönetici), nâzır (denetçi), kâtip (yazıcı) ve câbî (tahsildar) gibi idarî personel ile müderris, imam, bevvâb, ferraş gibi hizmet personelinden oluşuyordu. ${ }^{30}$

“ 'An Zâbıtân-ı Vakf-ı Şerîf”' olarak da adlandırılan idari görevlilerden mütevellinin öncelikli görevi vakıf akar ve hayrâtının bakım ve onarımını en güzel şekilde yaptırmaktır. Mütevelli vakfiyede belirtilmiş olan mürtezikaya ücretlerini eksiksiz olarak vermek durumundadır. Ücretlerin ödenmesi konusunda mütevellilere düşen bir görev de ilgililerin maaş almaya hak kazanıp kazanmadıklarını tespit etmektir. Vakıfların, ziraî olsun, bina nitelikli olsun gelir kaynaklarının işletilmesi ve herhangi bir şekilde zarar görmelerinin önlenmesi, bina nitelikli gelir kaynaklarından olan musakkafât ve müstegallât üzerinde yapılacak en küçük değiş̧ikliklerin takibi bile mütevellinin görev ve yetkisi dâhilinde idi. İşbu vakfiyede de vakfın nezaret ve tevliyetini kaydı hayat şartı ile Emîr Tenkiz kendisine şart kılmıştı. Ve

\footnotetext{
${ }^{29}$ Bahaeddin Yediyıldız, "XVIII. Asır Türk vakıflarının iktisadî boyutu,” Vakıflar Dergisi, c. XVIII, (Ankara: VGM Yay., 1984$), 5$.
}

30 Nazif Öztürk, Türk Yenileşme Tarihi Çerçevesinde Vakıf Müessesesi, (Ankara: TDV Yay., 1995), 169. 
kendinden sonra evlâdının ve evlâd-1 evlâdının ve zürriyyetinin "el-erşed fe 'l-erşed" 31 (yaşça en büyük ve en olgun) usulü üzere en olgun olanına şart kılmıştır. Evlattan nesli kesildikten sonra azatlı kölesinin yaşça büyük ve olgun olanına şart kılmıştır. Ve onlardan sonra Kudüs-i Şerîf ve Medîne-i Halil'de bulunan Haremeyn-i Şerîfeyn nâzırına ve Kudüs kadısının ortaklığı ile ait olacaktır. Ve bu görevin Kadı'dan sonra yerine gelecek yeni Kadı'ya ve mütevelliden sonra yerine gelecek yeni mütevelliye olacak şekilde devam etmesini şart kılmıştır.

Vakfiyelerde vakıf hizmetlerinin sürdürülebilirliği ve kalitesi için istihdam edilen personelin mesleki yeterliliği, ahlaki vasıfları, yapacağı iş ve alacakları ücreti açıkça belirlenmiştir. Vakıf görevlilerin bu kişisel özelliklerinin yanı sıra sayıları gibi niceliksel özelliklerine ilişkin oldukça detaylı tanımlamalara vakfiyelerde rastlamak mümkündür. "Ehl-i vezâif, vakıf mürtezikası" gibi çeşitli şekillerde adlandırılan vakıf görevlilerinin belirlenmesi de yine vâkıfın iradesine tabi idi. Vâkıf burada öncelikle görevlilerde yapacağı iş gereği kişide uygun bulunması gereken vasıfları, görev tanımlarını, işin zamanını, alacakları ücretleri, uyulması gereken kurallar ve yaptırımları sıralar. Gerektiğinde yapılacak uyarıları, gerektiğinde verilebilecek cezaları ve personelle ilgili oluşturulan denetim mekanizmalarından söz edilir.

Tenkiziyye Medresesi Vakfiyesi'nde tespit edilen görevliler, ücretleri ile diğer tayinatları şu şekildedir:

Tablo 1. Tenkiziyye Medresesi Vakfiyesine Göre Vakıf Görevli Listesi ve Ücretleri ${ }^{32}$

\begin{tabular}{|c|c|c|c|c|}
\hline \multirow[b]{2}{*}{ İstifade Eden } & \multirow[b]{2}{*}{$\begin{array}{l}\text { Nakdî Vazîfe } \\
\text { (Gümüş } \\
\text { Dirhem/Aylık) }\end{array}$} & \multicolumn{3}{|c|}{ Aynî Vazîfe (Rıtl) } \\
\hline & & $\begin{array}{l}\text { Ekmek } \\
\text { (Günlük) }\end{array}$ & $\begin{array}{l}\text { Zeytinyağ } \\
1 \\
\text { (Aylık) }\end{array}$ & $\begin{array}{l}\text { Sabun } \\
\text { (Aylık) }\end{array}$ \\
\hline Müderris & 60 & 1 & & \\
\hline Mu'î̀d & 30 & $12 / 3$ & & \\
\hline $\begin{array}{l}\text { Müntehî (ileri seviyede) olan } \\
\text { fakîhlere }\end{array}$ & 20 & $1 / 2$ & & \\
\hline Orta derecede okuyan fakîhlere & 15 & $1 / 2$ & & \\
\hline $\begin{array}{l}\text { Mübtedî (başlangı̧̣ seviyesinde) } \\
\text { olan fakîhlere }\end{array}$ & 10 & $1 / 2$ & & \\
\hline Muhaddislerin şeyhine & 40 & 1 & & \\
\hline Kârî-i Hadîs-i Şerîf’e & 20 & $1 / 2$ & & \\
\hline Muhaddislerden her birine & 7,5 & 1 & & \\
\hline Sûfiye Şeyhine & 60 & 1 & 3 & 3 \\
\hline Mutasavviflarm her birine & 60 & $1 / 2$ & $1 / 6$ & $1 / 6$ \\
\hline Aş̧̧ı & 5 & & & \\
\hline
\end{tabular}

31 "Tevliyeti vâkıfın mutlaka evlâdının erşedine meşrûta olan vakfın tevliyetine, vâkıfın gerek zükur ve gerek inâs evlâdından hangisi en ziyâde reşid ise ol kimse müstehik ve meşrûtunleh olur." Ömer Hilmi Efendi, ithaf-ül-ahlâf, 86-87.

32 Arapça olarak hazırlanmış benzer bir Tablo için bkz. Hijjih and el-Tel, "el-Medrese el-Tenkiziyye", 99-100. 


\begin{tabular}{lcc}
\hline Hizmetçi & \multicolumn{1}{c}{5} \\
\hline $\begin{array}{l}\text { Misafir Sûfîlere (Ayda en fazla 10 } \\
\text { kişi) }\end{array}$ & $\begin{array}{l}\text { 1/2(günlük olarak, 15 gün } \\
\text { süre ile), gittiklerinde her } \\
\text { birine azı olarak } \\
\text { dirhem. }\end{array}$ & $1 / 2$ \\
\hline Kadınlar Ribâtının şeyhine & 10 & $1 / 2$ \\
\hline Kadınlar Ribâtının kayyımına & 10 & $1 / 2$ \\
\hline Kadınlar Ribâtının bevvâbına & 10 & $1 / 2$ \\
\hline $\begin{array}{l}\text { Ribâtta bulunan 10 hatunun her } \\
\text { birine }\end{array}$ & 7,5 & $1 / 3$ \\
\hline Kârî-i Kur'an'a & 15 & $1 / 2$ \\
\hline $\begin{array}{l}\text { Medresenin 2 kayyımının her } \\
\text { birine }\end{array}$ & 20 & $1 / 2$ \\
\hline Medresenin bevvâbına & 20 & $1 / 2$ \\
\hline \begin{tabular}{l} 
Abdesthanenin kayyımına \\
\hline
\end{tabular} & 10 & \\
\hline
\end{tabular}

Tablo 1'de zikredilen görevlilerin görevleri de zaman zaman detaylı bir şekilde vakfiyede tanımlanmıştır. Örneğin vâkıf, medreseye müderris olarak atanacak görevlinin özelliklerini şöyle tanımlamıştır: Kur'ân-1 Kerîmi hıfzeden, İmâm-1 Âzam Hazretlerinin mezhebini bilen bir kişi olması ve bu medresenin kıble tarafının yukarısı bulunan mescitte imam olup beş vakitte ve teravih namazında mevcut ve hazır bulunan Müslümanların namazını kıldırması ve tedris günlerinde hazır bulunan talebeye sabahda ve ikindiden sonra çeşitli ilimleri anlatması şeklinde sıralamıştır. Muhaddisleri ise, şeyh ve kıraatçı ve yirmi adet muhaddis olarak ayrılmış ve kıraatçinin zaptı ve kıraatı güzel olmasını ve tedris zamanında Sahih-i Buhârî, sonrasında Sahih-i Müslim okumasını ve tedris zamanlarında böylece devam edip gitmesini ve yirmi muhaddisin tederrüs günlerinde sabit hadislerden her gün bir hadis hıfzetmelerini ve bu hıfzettikleri hadisleri tedris zamanı bitince şeyhe arz etmelerini şart kılmıştır. Sufiler üzerine tayin olunan şeyhden ve on beş adet sofiden ibaret kimselerden birinin hadim ve birinin aşçı olmasını ve cümlesi her gün sabahları güneş doğmadan yukarı mescitte toplanıp her biri rahledeki Kur'ân-1 Kerimden müyesser olan kıraat edip bu kıraate yukarda beyan olunduğu vecih üzere son verdikten sonra Cenâb-1 Hakk'1 zikretmelerini ve sonra zikirlerini vakfiyede yazılı salavât-1 şerîfeden on adet salavât-1 şerîfe ile bitirmelerini şart kılmıştır. Ribâtta ise, müslüman, diyanetli, hayırlı, salahlı, dul yani bekâr, yaşını almış, ribâtta devamlı ikamet edici on iki fakir hatunun kalmasını şart kılmıştır. Bunlardan biri diğerlerine şeyh ve biri ribâta kayyıme ve gelen fakir hatunlara bevvab olacak ve şeyh olan hatun; diğerlerine beş vakitte ve teravih namazında imam olacak, kayyım ve bevvab olan kadın ise ribâtın sergilerini sermek ve süpürüp temizlemek ve ribâtın abdesthanesini yıkamak ve medresenin bevvabında geçtiği veçhile ribâtı muhafaza etmek ve çerağlarını yakıp söndürmek işlerini görecekti.

İncelenen vakfiyede kapsamlı hayır hizmetlerine de yer verilmiştir. Örneğin, mütevellinin her sene teravih namazı için elli gümüş dirhemlik mum alması ve medresenin kıble tarafının yukarısında bulunan mescitte tüttürülmek üzere buhurât-ı tayyibe (güzel kokular) alması ve benzer şekilde kurban bayramında iki sığır ve en iyisinden iki dişi koyun alıp bayram günlerinde kestirerek ehl-i vakfa ve sair 
Müslüman fakirlere münasip gördüğü şekilde dă̆ıtmasını şart kılmıştır. Yine vakfın mütevellisinin mum alıp her gün sabah namazından sonra medresenin eyvanı doğusunda mushaf-1 şerîf'den Kur'ân-1 'azîm okunduğu zamanda ihtiyaç miktarı yakılmasını talep etmiştir. Sahih-i Buhari ve Sahih-i Müslim'in hatimleri zamanında te'âmül ve tedâvül olunan dirhem ile yüz dirhem bedelinde helva alıp hazır bulunan muhaddislere ve sairlerine münasip gördüğü şekilde dağıtmasını şart etmiştir.

Teslim/Tesellüm- Sıhhat/Lüzum: Vâkıflar kurdukları vakıfları İslam hukuk kurallarına uygun olarak bir kadı veya bunun temsilcisi huzurunda kurarak, onayını alırlardı. Bu bölümde ise, vakfiyede bu işlemlerden sonra vâkıf bütün bu hükümleri tamamlayıp şahitler huzurunda tescil mütevellisine vakfını teslim etme süreci anlatılırdı. Yine bu bölümde, vakfiyelerin de hukuki bir statü kazanması açısından en yetkili kişi olan Kadı, vakfın şer'î hukuk hükümlerine göre kurulmuş, vakf-ı sahîh (doğru)/sahih vakıf mı, vakf-1 lâzım/ gerekli mi olduğuna dair, başka bir ifade ile vakfın sıhhat ve lüzumu konusu görüşlerine başvurulan din âlimlerine referansla tartışılarak, müessesenin şeriata uygunluğu hükmü yazılıdır. ${ }^{33}$

Vakfın yasal olması, bütün faaliyet alanlarının kuruluş sırasında vakfiyesinde belirtildiği şekliyle kayıt ve şarta bağlanmasına bağlıydı. Vakfın temel sermayesi olan gelir getiren mülkler daimî olarak temlik edilirdi. Yardım alacak kişilerin ve haleflerinin (kurum ya da kişiler) varlıkları sona erince binanın yıkılması ya da vâkıfın neslinin kesilmesi gibi durumlarda yani vakfın şartlarının uygulanamaz olduğu durumlarda gelirlerin ne şekilde harcanacağı da kaydedilirdi. Örneğin, Tenkiziyye Medresesi'ne ait bu vakfiyede vakfın şartlarını uygulamanın mümkün olmadığı durumlarda vakfın gelirleri fakir Müslümanlara şart koşulmuştur. Hemen hemen her vakfiyede bu sürecin tanımlanması ile vakfin sahih ve geçerli olduğunun hukuki dayanakları ile pekiştirilmesine ve ileride vakfın işleyişi ve sıhhati ile geçerliliği konusunda ortaya çıkabilecek sorunların da önüne geçilmesine çalışılmıştır.

Vâkıfın Dua veya Bedduası: Burada vâkıfın vakfının devamı için bazı kurallar sıraladığı görülür. Bunlardan bazıları hayır dua, bazıları da beddua şeklindedir. Ayrıca, vâkıfın vakıf hizmetlerinde gerek yönetici gerekse diğer görevlilere/vazîfelilerine hem vakıf hizmetlerinin yürütülmesi sırasında doğru ve dürüst davranmaları ve hizmeti aksatmamaları için hem de onların ahiret hayatları ile ilgili bir uyarıdır. Vakfiyede belirtilen hizmetleri yerine getirmeyen, ona ihanet eden, onu gayesinin dişında kullanan idareci ve görevlilere de beddua edilmektedir. Vakfı kötüye kullanan, onu değiştiren, bilerek zarar veren, gelirlerinin azalmasına sebep olan, haksız olarak vakıf malından yiyen vs. gibi, vakfa kötülügü dokunan veya dokunacakları hedef alır.

Vakfiyenin en sonunda ise "şuhûdü'l-hâl" olarak adlandırılan ve çoğu durumda unvan/lakab ve sosyal konumu hakkında bilgilere de yer verilen şahitlere ilişkin kayıtlar bulunmaktadır.

$\mathrm{Bu}$ plan dahilinde hazırlanmış olan vakfiyeler kadılarca mahkeme sicillerine kaydettirilmekte ve asılları da tayin edilmiş mütevellilere verilmekteydi. ${ }^{34}$ Medreseye ait bu vakfiyenin sonunda vakfiye tarihi 12 Cemaziyelevvel 730/ 3 Mart 1330 olarak kaydedilmişti.

\section{Osmanlı Döneminde Şer'î Mahkeme Olarak Kullanılan Tenkiziyye Medresesi}

Tenkiziyye Medresesi'ni konu alan bazı kaynaklarda medresenin Osmanlı Dönemi'nde şer'î mahkeme olarak kullanıldığına işaret edilmiştir. Memlükler Dönemi'nde Kubbetü’l-Yusuf şer'î mahkeme olarak kullanılırken, Osmanlı Dönemi’nde Harem'in girişinde, Babü's-Silsile yakınındaki

\footnotetext{
33 Joseph Schacht, "Early Doctrines on Waqf”, Fuad Köprülü Armağanı, (İstanbul: Osman Yalçın Matbaası, 1953$), 447$.

34 Yediyıldız, XVIII. Yüzyılda, 4-5.
} 
Tenkiziyye Medresesi şer‘î mahkeme olarak kullanıldığı kaydedilmiştir. ${ }^{35}$ Ürdün yönetimi döneminde mahkeme, Kudüs Harem-i Şerîfi dışında Salahaddin Caddesi’ne taşınmıştır.

Evliya Çelebi 17. yüzyıl ortalarında ziyaret ettiği Kudüs Mahkemesi'nin sorumluluklarından bazılarını tasvir etmiştir. ${ }^{36}$ Buna göre, kentin ekonomik faaliyetleri, şeyhü's-sûk, muhtesib, keyyâlbaşı (terazileri denetler) ve bütün tüccar ve zanaatkârları temsil eden şeyhü't-tüccarla birlikte kadı mahkemesi tarafindan yönetilirdi. ${ }^{37}$ Kudüs'te dört İslam mezhebinin de kadıları olmasına rağmen baş kadı Osmanlı Devleti'nin resmî mezhebinden, yani Hanefiydi. Bu kişi ilmiye sınıfının kıdemli bir mensubu olurdu, her yıl İstanbul'dan atanırdı. Şafî, Malikî ve Hanbelî mezheplerinden olan öteki kadılar, yerel 'ulemâ arasından seçilebilirdi. Kudüs'te dört mezhepten de kadı bulunması, başka yönlerden gayet mütevazı olan bu taşra şehrinin dinsel açıdan ne kadar önemli olduğunu gösterir. ${ }^{38}$ Kudüs kadıları Şam'da bulunan, ilmiye sınıfına ve Hanefî̀ mezhebine mensup baş kadının denetimi altındaydı. ${ }^{39}$ Yetki alanı sancak sınırlarını aşan Kudüs kadısı, sicillerde Kudüs Sancă̆g, El-Halil kenti ve Beyt Cibrîn kalesi ile bağlı yerleri kapsayan adlî bölgenin amiri olarak tanımlanıyordu. El-Halil, Beyt Cibrin, Remle, Gazze ve Nablus gibi kasaba ve bazı büyük köylerin kendi kadıları vardı; ama buralarda yaşayanlar zaman zaman Kudüs Kadısı'na başvuruyorlardı. Bu tür davaların konusunu Kudüs'teki vakıf malları, Kudüs'teki kutsal yerlere ait vakıflar oluşturuyordu. ${ }^{40}$

1690-1834 yılları arasında Kudüs Kazasına ait 'askerî zümreye ait atama kayıtlarının yer aldığı Hurûfât defterlerinde medreseye ilişkin Rebiulevvel 1137- Ramazan 1159/ Aralkık 1724- Ekim 1746 tarihleri arasında yedi atama kaydı tespit edilmiştir. Öte yandan, "Vakf-ı Buk' $\hat{a}-i$ ve Hangâh-ı Tenkiziyye der-Kudüs-i Şerîf” başlıklı vakfın atîk (hazîne) atama kayıtlarında ise; Şa “ban 1130- Receb 1200/ Temmuz 1718- Mayıs 1786 tarihleri arasında vakfa 13 atama yapıldığı tespit edilmiştir. Bahse konu kayıtlarda öncelikle, Osmanlı Dönemi'nde vakfa idari ve hizmet görevlileri atanmaya devam edildiği görülmektedir. İkinci olarak vakıf görevlerinin hisselendirildiği dikkat çekmektedir. Medreseye atama yapıldığına dair son kayıt 29 Receb 1200/ 28 Mayıs 1786 tarihlidir. Bu durum, medresenin bu tarihten sonra $\mathrm{m} 1$ şer'î mahkemeye dönüştügü yoksa önceki dönemde de vakıf ve şer'î mahkeme hizmetlerinin beraber yürütüldüğü sorularını akla getirmektedir.

Osmanlı yönetiminin daha geç bir döneminde Medrese'ye ilişkin Kudüs yakınında Abû Dîs'te bulunan İhyâu't-Turâs ve'ş-Şu 'ûnu'd-Dîniyye Müessesetu Ihyâu't-Turâs ve'l-Buhûsu'l-İslamiyye Kurumu Arşivi'nde ve 1330-1335 yılları arasında çeşitli tarihlerde kaleme alınan 35 belgeden oluşan bir dosya çalışma çerçevesinde incelenmiştir. Belgelerin bir kısmı harap olan yapıların ihtiyaç duyduğu

\footnotetext{
35 Dror Ze'evi, Kudüs: 17. Yüzyılda Bir Osmanlı Sancağında Toplum ve Ekonomi, çev. S. Çağlayan, (İstanbul: Tarih Vakfı Yurt Yayınları, 2000), 29.

36 “... Ve dahi mollanın destinde mahkeme hidmetine me’mûr berât-ı pâdişâhî ile yirmi ağalık vardır. Evvelâ muhzırbaşı rikâb-ı hümâyûn tarafından keçeli kapucıdır. Rü'ûs-ı hümâyûn ile zabt ider. Ikinci Ağa Kudüs-i Şerîfe gelen su nâzırı Mükellef ağalıkdır. Üçüncü Ağa mimarbaşı ve dördüncü mühendisbaşı ve beşinci mu'temedbaşı ve altıncı sarrafbaşı. Cemii ulemaya surre [i] padişahîgeldi elinden çıkar. Ve yedinci Ağa veznedarbaşı ve sekizinci subaşı ve dokuzuncusu bazarbaşı ve onuncu şehir kethüdası ve on birinci bezazistan kethüdası. Hulâsa-i kelâm cemi esnafin şeyhleri her gün mahkemede hazır olup hidmet iderler." Evliyâ Çelebi, Seyahatnâme (Hatay, Suriye, Lübnan, Filistin), Haz. Ismet Parmaksızoğlu, (Ankara: K.T.B. Yay., 1982), 463.

37 Ze'evi, Kudüs: 17. Yüzyılda, 30. Klasik dönemde Osmanlı kentinin yönetimi ve yargı görevi ilmiye sınıfına mensup kadılarca yürütülmekteydi. Sancağın en büyük adlî yetkilisi olan kadı, sancakbeyinden ayrı ve onu tamamlayıcı bir otoriteyi temsil ediyordu. Kadının sancak yönetimindeki ağırlığı, en üst askerî yetiliye eşit ve yargıç unvanının kapsamını aşacak büyüklükteydi. İyi yönetim ve yolsuzluk gibi konularda, ona da sancakbeyine olduğu gibi padişahtan düzenli olarak fermanlar geliyordu. İsmail H. Uzunçarşılı, Osmanlı Devleti'nin IImiye Teşkilâtı, (Ankara: TTK Yay., 1988), 105.

${ }^{38}$ Amy Singer, Kadılar, Kullar, Kudüslü Köylüler, çev. Sema Bulutsuz, (İstanbul: Tarih Vakfı Yurt Yayınları, 1996$), 37$.

${ }^{39}$ M. Adnan Bakhit, The Ottoman Province of Damascus in the Sixteenth Century, (Beyrut: Librarie du Liban, 1982 ), 123.

40 Singer, Kadılar, Kullar, 38.
} 
tamiratların kaydedildiği keşif defterleri olup, ${ }^{41}$ bir kısmında da kiraya verilen vakıf mülklerine ilişkin kayıtlar yer almıştır. ${ }^{42}$

$\mathrm{Bu}$ dosyada yer alan belgelerden ilkinin 24 Nisan 1330/7 Mayıs 1914 tarihinde gönderilen yazıya cevap olarak kaleme alındığı ve Kudüs'te bulunan Tenkiziyye Medresesi Vakfi hakkında Kuyûd-ı Hakânî (Tapu Kayıtları) tarafından yazılan der-kenarın da yazı ekinde gönderildiği bildirilmiştir. Evkâf Nâzırı adına Müsteşar tarafından kaleme alınan yazının yazıldığı dönemde Medrese Vakfı'nın durumu anlatılmıştır. ${ }^{43}$ Şer‘î Mahkeme tarafından "işgal” edilen medresenin aslına dönmesi ve yazı ekinde gönderilen Kuyûd-1 Hakânî İdaresi'nin yazısında belirtilen 'Ayn-ı Kînâ köyünün vakfedilen hasılatına müdahale edilmeyerek gerekenin yapılması istenilmiştir. Yazının devamında ise dosyada yer almayan ve Musa Şefik mührüyle gönderilen arzuhâlde belirtilen medreseye ait vakfiyenin tasdikli bir örneğinin Hazine tarafından tescil edilmek üzere gönderilmesinin gereği bildirilmiştir.

Yazıda bahsedilen ve aynı dosya içerisinde yer alan 11 Haziran 1330/ 29 Haziran 1914 tarihli Kuyûd1 Hakânî kaydında ise; 'Ayn-1 Kînâ olarak adlandırılan ve çiftlikler ve mezra'alardan oluşan köyün gelirlerinin taksimatı detaylı bir şekilde kaydedilmiştir. ${ }^{44}$ Buna göre; Tenkiziyye Medresesi Vakfı'na ait vakfiyede 'Ayn-1 Kînâ köyünün bütün çiftlik ve mezra'alar ile gelirlerinin tamamının medreseye vakfedildiği kayıtlı olmasına rağmen, 29 Haziran 1914 tarihinde Kuyûd-1 Hakânî İdaresi tarafından gönderilen bu yazı ile gelirlerin ancak 1/3'ünün medreseye verildiği, kalan kısmına ise Maliye Hazinesi tarafından el konulmakta olduğu bildirilmektedir.

Dosyada yer alan ve Evkaf Nâzırı adına müsteşar imzasıyla gönderilen 23 Haziran 1330/6 Temmuz 1914 tarihli yazıda ise; Kudüs'ten Musa Şefik mührüyle gönderilen arzuhâlde zikredilen ve Kudüs Kadılığı tarafindan tescil edildiği bildrilen vakfiyenin, Kuyûd-ı Hakânî İdaresi'ne tescil edilmek üzere gönderilmesi talep edilmiştir. ${ }^{45}$ Yazışmalarda şer‘î mahkemenin işgalci konumunda olduğunun anlaşılması üzerine öncelikle medresenin vakfına dönmesine ve Kuyûd-ı Hakânî İdaresi’nin ‘Ayn-1 Kînâ karyesi gelirleri ile ilgili olarak da gerekeni yapması emri verilmiştir.

Bu yazı üzerine 17 Nisan 1332/30 Nisan 1916 tarihli yazıda; “Kudüs-i Şerîf'de Ebu Said Tenkiz Medresesi Vakfi'na aid olub 19 Şubat 1330/4 Mart 1915 tarih ve 6420/168 numrolu tahriratınizla gönderilen vakfiye sureti Kuyûd-ı Vakfiye İdaresince tescil idilmiş olmağla sahibine virilmek üzere leffen irsal kılındı. Kaydiyesi olan elli guruşun sahibinden ahzi lüzûmu beyan olunur." denilmiştir.

${ }^{41}$ Belgeler: 05,06,07,08,

42 Ihyâu't-Turâs Arşivi, Kutu No:66, Dosya No:3/6/1/52/1330/13, Belgeler 10, 12, 13, 14, 15,16,17,18,19,20.

43 "...Zikr olunan medresenin el-yevm Mahkeme-i Şer'iyye tarafından işgâl idilmekde olduğu iş'âr olunmasına göre evvelen istirdâdıyla hâl-i 'aliyyesine ircâ'ı ve onu mute'âkip Kuyûd-ı Hakânî Idaresi'nin der-kenârında gösterilen 'Ayn-ı Kînâ karyesi hâsılât-ı mevkûfesinin ahz ve istihsâlı esbâbına tevessül idilmesi lâzım geleceği beyânıyla ol-vecihle îfâ-yı muktezâsı ve bir de vakf-ı mezkûrun oraca müseccel olduğu Musa Şefik mührüyle virilen azruhâl metninde zikr olunan Vakfiyesi Hazînece de tescil olunmak üzere musaddak sûretinin Nezârete irsâli lüzumu tevcîh olunur." ihyâu't-Turâs Arşivi, Kutu No:53, Dosya No: 3/6/0/3/1284/13.

44 "Kuyûd-ı Hakânî̀ye lede'l-mürâca'a Kudüs-i Şerîf Nâhiyesinde tâbi' Vakfü'l-Emîr Tenkiz 'alâ Medrese fî Bâbü's-Silsile ve Ribâtu'n-Nisâ der-Kudüs-i Şerîf ve zîrinde 'an karye-i 'Ayn-ı Kînâ tâbi'i Kudüs-i Şerîf hisse-i sekiz kırat me'a mevadd-ı sâire ve yine Nahiye-i mezbûreye tâbi' Karye-i 'Ayn Kînâ hâsıl-ı kısm mine's-sülüs 4200 akçe ve hisse-i Vakf-ı Medrese-i Tenkiziyye der-Kudüsi Şerîf 8 kırat 1400 akçe ve hisse-i tımar 16 kırat 2800 akçe ve'l-öşür 'an mâl-ı vakf ve resm-i meced ve temel sâire ki; cem'an yekûn hisse-i tımâr me'a 'öşr ve rüsûm 3500 akçe deyû mukayyed bulunmuş olduğuna binâen sâlifü'z-zikr 'Ayn-ı Kînâ Karyesinin kısm-ı mine's-sülüs hâsılatının 24 kırat itibariyle 8 kırat hissesinin Kudüs-i Şerîfde vâki' Denkiziyye Medresesi Vakfı tarafından ve bâki 16 kırat hissesiyle el-öşr 'an-mâl-ı vakf hâsılât ve rüsûmâtının Maliye Hazîne-i Celîlesinden zabt olunması iktizâ ideceğinin beyânıyla işbu evrak Evkâf-ı Hümâyûn Muhasebe-i 'Umûmiye Müdiriyeti Behiyyesine iade kılndı. 11 Haziran 330." ihyâu't-Turâs Arşivi, Kutu No:53, Dosya No: 3/6/0/3/1284/13.

45 ihyâu't-Turâs Arşivi, Kutu No:53, Dosya No: 3/6/0/3/1284/13, Belge No:4. 
VGMA'da mevcut vakfiyenin tescil tarihine dikkat edilecek olursa 3 Rebiu'l-evvel 334 [09/01/1916 M.] olduğu görülür. Bu tarihler de zamanlama açısından birbiri ile uyumludur.

$\mathrm{Bu}$ yazıdan yaklaşık 23 gün sonra yapılan yazışmada ise; Kudüs-i Şerîf Mahkemesi ile Kudüs Mutasarrıflığı arasındaki 29 Rebiulevvel 1333/14 Şubat 1915 tarihli yazıda medresenin yazının kaleme alındığı tarihten 311 yıl önce yani 1604 yılında şer'î mahkeme tarafından alındığı kaydedilmiştir. ${ }^{46}$ Evkaf Nezâreti tarafından gönderilen yazı ile de Tenkiziyye Medresesi'nin boşaltılarak Vakfı tarafina teslim edilmesinin irade buyurulduğu bildirilmiştir. Öte yandan, 730/1330 tarihli vakfiyenin Kudüs şer'iye siciline kaydedildiği/tanzim edildiği ikinci tarih 1020/1611 y1lı olup, bu el koymadan yaklaşık 5 yıl sonradır. Dolayısıyla, şer'î mahkeme tarafından el konulan medrese binasının vakıf olduğunu gösterir vakfiyesinin yaklaşık 5 yıl sonra şer'î mahkeme sicillerine ikinci kez kaydedilmesine rağmen, medrese binasının neden mahkeme tarafından kullanılmaya devam edildiği sorusu bu noktada tekrar gündeme gelmektedir. Medrese binası 1604 yılından itibaren şer'î mahkeme olarak kullanılmaya başlanmışsa, idari bir arşiv olan VGMA'da kayıtlı H. 1130-1200/ M. 1718-1786 tarihleri arasında medreseye yapılan görevli atamalarının ne anlama geldiği sorusu da bu noktada önem kazanmaktadır. ${ }^{47}$

Öte yandan, 20. yüzyılın ilk yarısında Kudüs’ten gönderilen bir arzuhâl üzerine yeniden tescil edilen vakfiye kaydının ardından, şer'î mahkemenin medrese binasını boşaltarak, ayrı bir yerde uygun bir yer kiralaması emredilmiştir. Bunun için de Şeyhülislamlık Makamı'ndan kira bedeli olarak 5330 kuruşun yeni mahkeme binasının kira bedeli olarak gönderildiği bildirilmiştir. ${ }^{48} \mathrm{Bu}$ yazının altına 10 gün sonra düşülen notta ise yazışma tarihinin üzerinden 3 ay geçmesine rağmen şer'î mahkemeye münasip bir yer bulunamadığının arz edildiği kayıtlıdır. ${ }^{49}$

Burada medresenin vakfiyesinin tescilinin ardından, hayrâtın akara tebdîl edilmediği açıkça görülmüştür. Ancak medresenin vakıf olduğunun anlaşılması ve boşaltılması talebi üzerine ayrı bir yere taşınmanın mümkün olmadığı şartlarda şer'î mahkemenin belirli bir kira bedeli karş1lığında medresede kalmasına müsaade edildiği görülmüş̧ür. Bunun için de Kudüs Evkâf Müdürü Cemil Bey ile Kudüs’te mukîm Kudüs Kadısı Sultan Saray Efendi arasında "Bâbü's-Silsile Mahallesinde Medrese-i Tenkiziyye nâm Medresenin fevkanî ve tahtanî me 'a müştemilatı hâvî bir bâb hâne" olarak tanımlanan medrese 45 Osmanlı parasına kiraya verilmiştir. ${ }^{50}$ Dosyada yer alan sonraki yazışmalarda ise örneğin 1334/1916 senesinin ilk üç ayının kirasının ödenmediği, 1335/1916-1917 yıllarına ait toplam 4617 guruş kira bedelinin ise Evkâf Sandığına teslim edildiği kayıtlıdır. ${ }^{51}$

Konu İslam fikhı açısından değerlendirildiğinde ise; vakıf mülklere ilişkin uygulamalarda yaygın bir şekilde karşımıza "istibdâl” örnekleri çıkmaktadır. İstibdâl, bir vakıf malı mülk olan diğer bir mal ile değiştirmek anlamına gelmektedir. İslâm hukukçularının bazıları vakıf malların asla değiştirilemeyeceğini ileri sürerken, diğer bazıları ise istibdâlin cevazını kabul etmişlerdir. ${ }^{52}$ Ömer Hilmi Efendi bir vakıf akarın istibdâl olunması hakkında vakıf kurucusu tarafından bir şart ortaya konulmamışsa, o surette o akarın istibdâlinin caiz olmadığını belirtir. Ancak bu akar vakıf için asla gelir getirmez veya getirdiği gelir o akarın masrafina yetmez bir hale geldiğinde vakıf için yarar olduğu

46 ihyâu't-Turâs Arşivi, Kutu No:66, Dosya No:3/6/1/52/1330/13, Belge No: 26.

47 Bahse konu görevli atamalarından 13'ü Atîk (Treasury) defterlerden 515 no'lu defterde, kalan 7 atama ise 'Askerî Rûznâmçe defterlerinde kayıtıdır. Görevli atamalarına ilişkin detaylı bilgi için sırası ile bkz. VGMA, 515: 73/81; 1119/110/32; 1128: 68/15; 1139/87/23; 1139/87/24; 1139/87/30; 1139/87/31; 1112/1/67

48 ihyâu't-Turâs Arşivi, Kutu No:66, Dosya No:3/6/1/52/1330/13, Belge No: 26.

49 ihyâu't-Turâs Arşivi, Kutu No:66, Dosya No:3/6/1/52/1330/13, Belge No: 26.

50 ihyâu't-Turâs Arşivi, Kutu No:66, Dosya No:3/6/1/52/1330/13, Belge No: 31.

51 ihyâu't-Turâs Arşivi, Kutu No:66, Dosya No:3/6/1/52/1330/13, Belge No: 32,35.

52 Ahmed Akgündüz, İslam Hukukunda Osmanlı Tatbikatında Vakıf Müessesesi, 2. Baskı, (Ankara: TTK Yay., 1988), $377-387$. 
hükmüne de varılırsa, o surette kadı onayı ve Sultan'ın izni ile istibdâlin câiz olduğunu ilave eder. ${ }^{53}$ Ebu Yusuf'un istihsân ve klyas esaslarına göre yaptığı tarifte, yani paranın yeni bir vakıf için kullanılması şartıyla para ile istibdâl kabul edilirdi. Ancak bunun için gayrimenkullerin satın alınması ve satışın satıcı aleyhine olmaması şartı getirilmişti. Örneğin, camiler için istibdâle izin verilmemiştir, çünkü camiler gelir getirmek üzere yapılmamışlardır. ${ }^{54}$ Van Leeuwen'de aktarıldığı şekliyle istibdâl meselesi ile ilgilenen kadı İmâdüddin İbrahim et-Tarsûsî arazilerin harap olduğu ve artık kullanılamaz hale geldiği durumlarda istibdâlin vakfın menfaatine olduğunu zikretmiştir. ${ }^{55}$

1700-1800 yılları arasında Kudüs’te kurulan vakıfları çeşitli açılardan inceleyen El-Madani, bahse konu yıllar arasında üçü hayrî, on dörtü de zürrî vakıftan olmak üzere toplamda on yedi vakıf akarına istibdâl uygulandığını kaydetmiştir. Hayrî vakıflardan, Zâviye-i Muhammed el-Kırımî, Bîmaristân-ı Salâhiyye ve Tebâne Mahallesi'nde bulunan Câmi-i Ömerî vakıflarının akarlarının istibdâl usulü ile değiştirildiğini belirtmiştir. ${ }^{56}$

Kudüs'ten İstanbul'a gönderilen bir şikâyet üzerine kaleme alınan ve Şam Ahkâm Defterlerinde yer alan konuya ilişkin bir hükümde ise; Kudüs kentinde bulunan Halil Efendi ve Hoca Salih ibni Şehâbeddin Kâtib Efendi Vakfi'nın mütevellileri Bâbü'l-'Amûd Mahallesi'nde bulunan vakıf arsa üzerindeki ev ile Şeyhü'l-Bekâ Mahallesi'nde bulunan yine bir evin istibdâline tâlip olduklarını bildirmişlerdir. Kadı ise istibdâlin değerinden fazla ya da eksik olmadan alınan fetvaya uygun şekilde yapılmasını hükme bağlamıştır. ${ }^{57}$

Öte yandan, vakıf hayrât eserlerinin akara tebdîli caiz değildir. Ancak bazı zaruri durumlar ile ihtiyaç dâhilinde hayrî bazı vakıf yapıların fonksiyonlarının değiştirildiği örneklere rastlamak da mümkündür. Osmanlı tatbikinde bazı örneklerde yangın gibi çeşitli gerekçelerle harab ve bazen de yok olan vakıf hayrâtın yerine aynı ya da başka amaçla yeni hayrât yaptırıldığı görülmüştür. Örneğin, Abdullah oğlu Has Odabaşı Hasan Ağa'nın gurre-i Zilhicce 1059/6 Aralık 1649 tarihli vakfiyesinde İstanbul Kumkapı'da Nişancı Paşa-yı Atîk yakınında bulunan ve Havuzlu Mescid olarak bilinen mescidin yandığı ve vâkıfın bu mescidi Sultan'ın da izni ile minber vaz' ederek vakit namazları ile Cuma namazının kılınabileceği bir cami inşa ettirdiği kayıtlıdır. ${ }^{58}$ eş-Şeyh Ahmed Rıfat Efendi bin el-Hac Selim Efendi Vakfi'na aid 1308/1628 tarihli vakfiyede ise, Karaca Paşa Mahallesi'nde bulunan Karaca Paşa Câmi-i Şerîf ve müştemilatının zamanla harab olduğu ve yıkıldığı, vâkıfın ise bahse konu camiyi imar ve ihyâ ederek, dergâh ve tevhidhâne ilave ettiği kayıtlıdır. ${ }^{59}$

Bazı örneklerde ise ihtiyaca binaen az sayıda da olsa vakıf eserlerin fonksiyon değişiklikleri görülmüş̦tür. VGMA'da kayıtlı Kayd-1 Hakânî'de Karahisâr-ı Sâhib (Afyon)'da bulunan Çerçi Durgud Baba Zâviyesi imaretinin gelen gidenlere yemek verdiği ancak zamanla Kadı'ların bazı yeni görevler ihdas ettiği, bu eli-beratlı yeni görevlilerin de zamanla zâviyede kimseleri misafir etmediği ve vakıf gelirlerini kendilerinin tasarruf ettiklerinin anlaşıldığı kayıtlıdır. Bu durumun bildirilmesi üzerine zâviyenin medreseye dönüştürülmesi ve gelirlerinin de ilim tedrisine ve öğrencilere sarf edilmesinin fermân-ı hümâyûnî ile uygun görüldüğü bildirilmiştir. ${ }^{60}$

\footnotetext{
53 Ömer Hilmi Efendi, ithaf-ül-ahlâf, 115.

54 Richard Van Leeuwen, Bir Osmanlı Şehri: Şam, Vakıflar ve Şehir, (İstanbul: Küre Yay., 2012), 55.

55 Van Leeuwen, Bir Osmanlı, 73.

56 Ziad Abdel Aziz al-Madani, Evkâfu'l-Kuds fî karn es-sâmin el-aşar el-mîlâdî, 1112H./ 1700 M.- 1214 H./ 1799 M. (The

Endowments of Jerusalem in the 18th Century), (Amman: Vezâreu's-Sakâfe, 2011), 122-123.

57 BOA, ADVNS.AHK.ŞM (4): 85/3.

58 VGMA, 571: 137/59.

59 VGMA, 989: 48/38.

60 VGMA, 1759.
} 
İhtiyaç dışında da zaman zaman yapıların fonksiyon değişiklilerine ilişkin örnekler bulmak mümkündür. Örneğin, Anadolu Abdâlları, Osmanlı Devleti'nin kuruluşunda gaziler (veya alp-erenler), ahîler ve bâcıyân-ı R̂̂m ile birlikle hizmetleri görülen dördüncü sosyal zümre idi. Abdâlân-ı Rûm, Âşıkpaşazâde'nin sözünü ettiği heterodoks (Râfizi) dervişler idi. ${ }^{61}$ Kendilerine Anadolu'da Seyyid Gazi Tekkesini (Eskişehir) merkez olarak kabul eden abdâllar, ${ }^{62}$ şeriat hükümlerini terkederek, Osmanlı yönetiminin kurallarına uymamaya, cemiyetin yaşayışıyla alay etmeye, kudümler, boynuzlar çalarak sokaklarda dolaşmaya başlamakta idi. Dervişlerin (1şık) hareketlerinden rahatsızlık duyan Süleyman I (1520-1566), İran seferinin dönüşünde Seyyid Gazi Tekkesini abdâllardan temizletip; onları oradan sürüp, Kütahya kalesine hapsettirirken, yalnızca re'âyânın şahitliği ile suçsuzluğu ifade edilen abdâllara serbestlik tanındı. Sadece Seyyid Gazi Tekkesi değil, Anadolu ve Rumeli'deki "ışık tekkeleri” ve zümreleri üzerinde de bir denetim kuruldu. Fuad Köprülü tarafından incelenen kaynaklardan, 980/1572 tarihli bir vesikada; Seyyid Gazi Tekkesi’nin, tamir edilmesi, medreseye dönüştürülen tekkedeki öğrencilere dostça davranılması, beş vakit namaza devam edilmesi, çıplak gezilmemesi gibi şartlarla Işık'ların tekkeye yerleşmelerinin kabul edildiği belirtilmektedir. ${ }^{63} \mathrm{Bu}$ örnekte de görüldügü üzere, Anadolu Abdâlları'nın tekkeleri medreseye dönüştürülmüştür.

Şeyh Mahmud Ebu Dakîka ise Ebu'l-Fazl Mecduddîn Abdullah bin Mahmûd bin Mevdûd elMevsılî’nin icmâ‘ yolu ile uygulanan ictihadî bir görüşünü verdiği bir örnekle şerhetmiştir. Şöyle ki; umumi bir yol var ise yoldan mescide, şayet yol dar olur ise de mescitten yola yer verilerek, mescidin ya da yolun alanının genişletilebileceği belirtilmiştir. Burada öncelikle her ikisinin -yol ve mescidinMüslümanlara ait olması gerekçe olarak bildirilmiş ve İmam Muhammed'in buna cevaz verdiği de ilave edilmiştir. İkinci olarak da mahkemede dava açılmaksızın şahitlik ikamesi ile arazinin hangisine tahsisinin tespitinin gerekliliği vurgulanmıştır. Yol mu yoksa mescit mi dar sorusu sorularak, mescitten yola, yoldan mescite genişletme yapılabileceğine hükmetmiştir. ${ }^{64}$

Hıdır Selami ise Kudüs'ün Osmanlı fethi sonrası tutulan ilk 15 şer'iye siciline dayandırdığı çalışmasında medreselerin konut olarak kullanımının Osmanlı döneminin başlangıcına denk geldiğini kaydetmiştir. Kiralanan medreselerin kadı izni ile kiralandığını gösterir örneklere yer vermiştir. $\mathrm{Bu}$ örneklerde, medresenin temel fonksiyonu olarak eğitim faaliyetlerinin devam ettiği, medreseyi konut olarak kullanan kişilerin ise bunun karşılığında medresenin tadilatı, döşenmesi ve aydınlatılmasının teminini üstlendikleri kayıtlıdır. ${ }^{65}$ Örneğin Kadı'nın caminin yenilenmesi, döşenmesi ve aydınlatılması, orada duaların tutulması ve çocukların yetiştirilmesi karşılığında Mukaddim bin Mustafa el-Tamari'ye Yusûfiye Medresesi'nde sâkin olma izni verdiği kayıtlıdır. Aynı şekilde Mâverdiye Medresesi'nde de yerleşilmiştir. Kiracı Sinan ve Aknaci, 2.000 Osmanî karşılığında medresenin yenilenmesi masraflarını üstlenmiştir. Duvar ustası Musallihiddin bin Abdullah'ın ifadesine göre de Bayram Çavuş'un medresesinin kubbesinin tamiri için 1600 Osmânî harcamıştır. Ancak bu örneklerde vakfa kira

\footnotetext{
61 Fuad Köprülü, "Abdâl”, Türkiye Diyanet Vakfı İslâm Ans., c. 1, (İstanbul: Türkiye Diyanet Vakfı Yayınları, 1988$), 61$.

62 Araştırmalar, "abdâl”" teriminin yerini aynı yıllarda "ışık" terimine terketmeye başladığı; Abdâl, Kalender, Bektaşî tabirlerinin yerine Işık teriminin yaygınlık kazanmaya başladığını gösteriyor. Bu da XVI. Yüzyılda Bektaşîliğin ve Hacı Bektaş-ı Veli'nin öğretilerinin abdâllar arasında tesirlerinin boyutlarını göstermektedir. Ayrıca, bu düşünceyi güçlendirecek bir başka kayıt da Katip Çelebi'nin Seyyid Gazi Tekkesi ile Hüseyin Gazi ve Yakup Tekkelerinin Bektaşî Abdâllarına mahsus olduğunu söylemesi, aynı şekilde Evliya Çelebi'nin bu tekkeleri Bektaşî Tekkeleri olarak kabul etmesidir. Bu durum, XVII. yüzyılda Bektaşîliğin kendi kanatları altına zümreleri alıp, genişlediğini göstermektedir. Köprülü, bu düşünceyi, Şeyh Galib’in bir manzumesi ve Esat Efendi'nin Üss-i Zafer adlı eserinde, Baba veya Abdâl lâkabı ile anılan tekke ve türbelerin Bektaşî velilerine has olduğunu belirterek doğrulamaktadır. Köprülü, "Abdal”, 33.

63 Köprülü, "Abdal", 31-32.

${ }^{64}$ Ebu'l-Fazl Mecduddîn Abdullah b. Mahmûd b. Mevdûd el-Mevsılî, el-ihtiyâr li ta'lîli'l-Muhtâr (el-Fıkhu'l-Hanefî), Beyrut: Dârü'l-Kütüb, 1998, 45.

65 Khadr Salameh, "Aspects of the Sijills of the Shari`a Court in Jerusalem", Ottoman Jerusalem: The Living City, 1517- 1917, Sylivia Auld and Robert Hillenbrand, der., (Londra: Altajir World of Islam Trust, 2000), 103-144.
} 
ödendiğine dair bir bilgiye yer verilmemiştir. Bu uygulamalar 18. yüzyılda Kudüs’te vakıf mülklerin kiralanmasında yaygınlık kazanan huluvv-l şer 'î uygulamaları ile benzerlik arz etmektedir. ${ }^{66}$

Netice itibariyle, yukarıda zikredilen örnekler göstermiştir ki, yangın, harap olma gibi zaruri durumlar ile bazı ihtiyaçlarda vakıf hayrâtının değişimi ya da akara tebdîli mümkün olabilmiştir. Ancak çalışma çerçevesinde incelenen belgelerde Tenkiziyye Medresesi örneğinde vakıf hayrât eserinin hangi gerekçe ile şer‘î mahkemeye tahsis edildiğine dair bir açıklamaya rastlanılamamıştır. Konuya ilişkin yukarıda incelenen dosyada ise, bu durum Medrese Vakfi'nın vakfiyesinin Kuyûd-1 Hakânî'de kayıtlı olmaması ve bu sebeple de bir vakıf hayrât olarak muamele görmemesi gerekçe olarak belirtilmiştir. Medresenin vakıf olduğuna ilişkin Kudüs'ten İstanbul'a gönderilen arzuhâl üzerine yapılan inceleme neticesinde, şer'î mahkeme tarafindan kullanılan medrese binasının İslam fikhına göre tanzim edilmiş bir vakıf medrese olduğu ve vakfiyesinin de daha önce iki kez tanzim edildiği anlaşıldıktan sonra vakıf medresenin şer‘î mahkeme tarafından kullanımının sonlandırılması ve Mîrî Hazine tarafından gelirlerine el konulan akarların gelirlerinin de vakfa dönmesinin gerekliliği emredilmiştir. Ancak devam eden savaş sartları nedeniyle kira karşılığında başka bir yere taşınamayan şer'î mahkemeye Şeyhülislamlık Makamı tarafından tahsis edilen kira bedeli karşılığında medrese binasının tahsis edildiği görülmüştür.

\section{Sonuç}

Memlük Döneminde İslam fikhına uygun olarak sahîh ve lazım bir vakıf olarak tanzim edilen Tenkiziyye Medresesi tarihsel süreci içerisinde hem mekânsal hem de işlevsel olarak pek çok değişime uğramıştır. Memlukler Döneminde medrese hizmet sunan yapı, Osmanlı Döneminde Şer‘î Mahkeme tarafından kullanılmıştır. Ancak 1915 yılında medresenin bir vakıf olduğu ve İslam hukukuna göre akar ve hayrâtının medreseye dönmesi gerektiği kararı alınmış, Şer‘î Mahkeme'nin medrese binasını boşaltması talep edilmişsir. Devam eden savaş şartları da dikkate alındığında kendisine yeni bir mekan bulamayan mahkeme, Şeyhülislamlık Makamı'ndan kendilerine tahsis edilen kira bedeli ile Tenkiziyye Medresesi vakıf hayrât binası üzerinde kiracı konumuna gelmiştir.

Tarihi süreçte mekânsal ve işlevsel bakımdan değişimler geçirmeye devam eden medrese, Harem-i Şerîf’e olan konumu ve sahip olduğu stratejik önemi nedeniyle İngiliz yönetimi döneminde de çeşitli şekillerde kullanılmaya devam edilmiştir. Yüksek İslam Meclisi Reisi Muhammed Emin el-Hüseynî tarafindan bir süre ikamet edilen medrese binası, sonrasında da İslam fikhı eğitim medresesi olarak kullanılmıştır. 1968 yılında ise İsrail sınır güvenliği gerekçesi ile medreseyi Polis Merkezine dönüştürmüştür. ${ }^{67}$ Günümüzde halen Polis merkezi olarak kullanılmaya devam edilen ve Harem-i Şerîf'in bir parçası olan Tenkiziyye Medresesi'nin alt ve üst katında olmak üzere iki sinagog inşa edilmiştir. Abdurrahman el-Mağribi'nin kanaati Kudüs'ün Yahudileştirilmesi planlarının bir parçası olarak nihai hedefin medresenin "Noor Yerushalayim" isimli çok daha büyük bir sinagoga dönüştürüleceği yönündedir. ${ }^{68}$

\footnotetext{
66 Vakıf mülklerin işletim usulllerine ilişkin detaylı bir inceleme için bkz. Şerîfe Eroğlu Memiş, “XVIII. Yüzyılda Kudüs’te Vakıf Mülklerin İşletim Usulleri: İcâre-i Vâhide, Hikr, icâre-i Tavîle ve Huluvv-i Şer î Uygulamaları", Journal of Islamicjerusalem Studies, (19) 1, 19-46.

${ }^{67}$ Abdurrahman el-Mağribi, "Târîh el-Medrese el-Tenkiziyye fî el-Kuds", Mecelletu'I-Câmi'atu'I-Islâmiyye li'l-Buhûsu'l-Insâniyye, vol. 20/2 (2012), 481-528.

68 el-Mağribi, "Târîh el-Medrese", 527-528.
} 


\section{KAYNAKÇA}

\section{Arşiv Kaynakları}

FÍLISTIN:

İhyâu't-Turâs ve'ş-Şuûnu'd-Dîniyye Müessesetu İhyâu't-Turâs ve'l-Buhûsu'l-İslâmiyye Arşivi, Abu Dis

Kutu No:53, Dosya No: 3/6/0/3/1284/13, Belge No:4.

Kutu No:66, Dosya No:3/6/1/52/1330/13, Belge No: 10, 12, 13, 14, 15,16,17,18,19,20,26, 31, 32,35.

\section{TÜRKIYE:}

Vakıflar Genel Müdürlü̆̆̈̈ Arşivi (VGMA)

Atîk (Hazîne) Defterleri/ Hurûfât ya da 'Askerî Rûznâmçe Defterleri:

515: 73/81; 1119/110/32; 1128: 68/15; 1139/87/23; 1139/87/24; 1139/87/30; 1139/87/31; 1112/1/67.

Vakfiye Defterleri:

571: 137/59; 601-1: 55/63; 989: 48/38; 1759.

\section{Başbakanlık Osmanlı Arşivi (BOA)}

BOA, ADVNS.AHK.ŞM (4): 85/3.

\section{Yayınlanmış Eserler}

Abdulmehdî, Abdulcelil Hasan. el-Medâris fî̀ Beyti'l-Makdîs fi'l-Asreyni'l-Eyyûbî̀ ve'l-Memlûkî. Amman: Mektebetü'l-Aksâ, 2009.

Akgündüz, Ahmed. İslam Hukukunda Osmanlı Tatbikatında Vakıf Müessesesi, 2. Bask1. Ankara: TTK Yay., 1988.

el-'Arif, ‘Arif. el-Mufassal fî Târîhi'l-Kuds. Kudüs, 1961.

el-'Arif, 'Arif. Tarîh-i Kubbetü's-Sahratullahü'l-Müsserrefe ve'l-Mescidü'l-Aksâ ve limahhatu 'an Târîhi'l-Kuds. Kudüs: Mektebetü'l-Endülüs, 1947.

el-Aselî, Kamil Cemil. “Kudüs,” Diyanet Vakfi İslam Ansiklopedisi, C.26 (2002): 334-338.

Bakhit, M. Adnan. The Ottoman Province of Damascus in the Sixteenth Century. Beyrut: Librarie du Liban, 1982.

Berki, Ali H. Vakfa Dair Yazılan Eserler ile Vakfiye ve Benzeri Vesikalarda Geçen Istılah ve Tabirler. Ankara: VGM Yay., 1966.

Bernardini, Michele. "Popular and symbolic iconographies related to Haram al-Sharif during the Ottoman period," S. Auld and R. Hillenbrand (ed.), Ottoman Jerusalem, the living city: 1517-1917. (London: Altajir World of Islam Trust, Jerusalem 2000): 95-103.

Burgoyne, Michael H. Mamluk Jerusalem: An Architectural Study. London: Published on behalf of the British School of Archaeology in Jerusalem by the World of Islam Festival Trust, 1986.

Canaan, Taufik. "Water and 'The Water of Life' in Palestinian Supersitition", Journal of the Palestine Oriental Society 9: 57 (1929): 57-69.

Eroğlu Memiş, Şerîfe. “XVIII. Yüzyılda Kudüs’te Vakıf Mülklerin İşletim Usulleri: İcâre-i Vâhide, 
Hikr, İâre-i Tavîle ve Huluvv-i Şer ‘î Uygulamaları”, Journal of Islamicjerusalem Studies, (19) 1, (2019): 19-46.

Eroğlu Memiş, Şerîfe. “Osmanlı Taşra Toplumu ve Vakıf Kurumu: Kudüs, 1703-1831”, Hacettepe Üniversitesi, Sosyal Bilimler Enstitüsü Yayınlanmamış Doktora Tezi, 2016.

Evliyâ Çelebi, Seyahatnâme (Hatay, Suriye, Lübnan, Filistin). Haz. Ismet Parmaksızoğlu. Ankara: K.T.B. Yay., 1982.

Goitein, S. D. and Grabar, Oleg. “al-Kuds”, Encyclopedia of Islam, Second Edition, Vol. V. Leiden: E.J. Brill, 1978.

Grabar, Oleg. "A New Inscription from the Haram al-Sharif in Jerusalem," Jerusalem, Vol. IV, Constructing the Study of Islamic Art. Hampshire: Ashgate Publishing Limited, 2005.

Gül, Muammer. “11-13 yüzy1llarda Kudüs,” Doktora tezi, Frrat Üniversitesi Sosyal Bilimler Enstitüsü, Elazığ, 1997.

Heffening, W. "Waqf”, Encyclopedia of Islam, Second Edition. Leiden: E. J. Brill, 1934.

Hijjih, Shawkat Ramadan and el-Tel, Othman Ismael. "el-Medrese el-Tenkiziyye fî el-Kuds: nemûzecen li-idâreti'l-medâris ve evkâfihâ fî el-'asr el-Memlûkî” Ankara Üniversitesi İlahiyat Fakültesi Dergisi 56:1 (2015): 77-106.

Köprülü, Fuad. "Abdâl”, Türkiye Diyanet Vakfi İslâm Ans., c. 1, İstanbul: Türkiye Diyanet Vakfı Yayınları, 1988.

Köprülü, Fuad. "Vakıf Müessesesi ve Vakıf Vesikalarının Tarihi Ehemmiyeti," Vakıflar Dergisi, S. 1, (1938): 1-6.

el-Madani, Ziad Abdel Aziz. Evkâfu'l-Kuds fi karn es-sâmin el-aşar el-mîlâdî, 1112 H./ 1700 M.- 1214 H./ 1799 M. Amman: Vezâreu's-Sakâfe, 2011.

el-Mağribi, Abdurrahman. "Târîh el-Medrese el-Tenkiziyye fì el-Kuds", Mecelletu'l-Câmi'atu'lİslâmiyye li'l-Buhûsu'l-İnsâniyye, vol. 20/2 (2012): 481-528.

el-Mevs1lî, Abdullah bin Mahmûd bin Mevdûd, el-İhtiyâr li ta 'lîli'l-Muhtâr (el-Fikhu'l-Hanefí), C. 34, Beyrut: Dârü'l-Kütüb, 1998.

Orbay, Kayhan. "Vakıfların Bazı Arşiv Kaynakları (Vakfiyeler, Şeriyye Sicilleri, Mühimmeler, Tahrir Defterleri ve Vakıf Muhasebe Defterleri)", Vakıflar Dergisi, 39 (2005): 27-41.

Ömer Hilmi Efendi. İthaf-ül-ahlâffì ahkâm-il-evkaf. Ankara: VGM Yay., 1977.

Öztürk, Nazif. Türk Yenileşme Tarihi Çerçevesinde Vakıf Müessesesi. Ankara: TDV Yay., 1995.

Pedersen, Johns. "Mescit”, İslam Ansiklopedisi, C. VIII, İstanbul: Milli Eğitim Bakanlığı Yay., 1993.

Powers, David S. "Revenues of Public Waqfs in Sixteenth Century Jereusalem", Archivum Ottomanicum, Vol. 9, Germany: Wiesbaden,1984: 163-202.

Salameh, Khadr. "Aspects of the Sijills of the Shari'a Court in Jerusalem," Ottoman Jerusalem: The Living City, 1517- 1917. Sylivia Auld and Robert Hillenbrand, der., Londra: Altajir World of Islam Trust, 2000: 103-144.

Schacht, Joseph. "Early Doctrines on Waqf," Fuad Köprülü Armăganı. İstanbul: Osman Yalçın Matbaas1, 1953.

Singer, Amy. Kadılar, Kullar, Kudüslü Köylüler. Çev. Sema Bulutsuz, İstanbul: Tarih Vakfı Yurt Yayınları, 1996. 
Singer, Amy. Osmanlı'da Hayırseverlik- Kudüs 'te Bir Haseki Sultan İmareti, çev. Dilek Şendil. İstanbul: Yeni Türkiye Yurt Yay., 2004.

Tanman, Baha ve Çobanoğlu, A. Vefa. "Osmanlı Döneminde Kudüs: Kent Dokusu, Mimarlık ve Çini Sanatına İlişkin Bir Araştırmanın İlk Sonuçları," Ortadoğu'da Osmanlı Dönemi Kültür İzleri Uluslararası Bilgi Şöleni Bildirileri (25-27 Ekim 2000, Hatay). Ankara: Atatürk Kültür Merkezi Başkanlığı Yay., 2001: 519-528.

Tibawi, Abdüllatif. The Islamic Pious Foundations in Jerusalem. London, 1978.

Tomar, Cengiz. “Kudüs” (Memlükler Dönemi), Diyanet Íslam Ansiklopedisi, C. 26, İstanbul, 2002.

Tütüncü, Mehmet. Turkish Jerusalem (1516-1917), Ottoman Inscriptions From Jerusalem and Other Palestinian Cities. Netherlands: SOTA, 2006.

el-‘Uleymî, Mucireddîn el-Hanbelî. el-Ünsü'l-Celîl bi-Târîhi'l-Kudsi ve'l-Halîl, c. II. Amman, 1973.

Uzunçarş11ı, İsmail H. Osmanlı Devletinin İlmiye Teşkilâtı. Ankara: TTK Yay., 1988.

Van Leeuwen, Richard. Bir Osmanlı Şehri: Şam, Vakıflar ve Şehir. İstanbul: Küre Yay., 2012.

Yediyıldız, Bahaeddin. "XVIII. Asır Türk vakıflarının iktisadî boyutu," Vakıflar Dergisi, c. XVIII, Ankara: VGM Yay., 1984: 5-41.

Yediyıldız, Bahaeddin. "Vakıf”, Isslam Ansiklopedisi, C. XIII, (İstanbul: MEB Yay., 1986): 153.

Yediyıldız, Bahaeddin. "Vakıf Müessesesinin XVIII. Asırda Kültür Üzerindeki Etkileri,” Türkiye’nin Sosyal ve Ekonomik Tarihi, yay. O. Okyar, H. İnalcık, Ankara, 1980: 157-159.

Yediyıldız, Bahaeddin. XVIII. Yüzyılda Türkiye'de Vakıf Müessesesi, Bir Sosyal Tarih İncelemesi. Ankara: TTK Yay., 2003.

Ze'evi, Dror. Kudüs: 17. Yüzyılda Bir Osmanlı Sancağında Toplum ve Ekonomi. Çev. S. Çağlayan, İstanbul: Tarih Vakfi Yurt Yayınları, 2000. 